\title{
An Overview of the Monitoring Program Design for the FutureGen 2.0 $\mathrm{CO}_{2}$ Storage Site
}

\author{
Vince R. Vermeul, James E. Amonette, Chris E. Strickland, Mark D. Williams, and Alain Bonneville \\ Pacific Northwest National Laboratory, Richland, WA. USA.
}

\begin{abstract}
As part of the FutureGen 2.0 Project, a design was developed for a first-of-its-kind, commercial-scale, near-zero emissions coal-fueled power plant that includes carbon capture and storage (CCS) in a deep saline reservoir. To assess storage site performance and meet the regulatory requirements of the Class VI Underground Injection Control Program for $\mathrm{CO}_{2}$ Geologic Sequestration, the FutureGen 2.0 Project evaluated, selected, and designed a suite of monitoring technologies for use in 1) evaluating $\mathrm{CO}_{2}$ mass balance, 2) detecting significant loss of $\mathrm{CO}_{2}$ containment, 3) tracking the spatial extent of the $\mathrm{CO}_{2}$ plume and advancement of the pressure front within the storage reservoir, and 4) identifying the occurrence and location of injection-related induced seismicity. The monitoring program design includes direct monitoring of the injection process (above ground and in the injection wells), injection-zone monitoring, early-leak-detection monitoring directly above the primary confining zone, and compliance monitoring within the lowermost underground source of drinking water (USDW); it also includes measurements of formation pressure and other geochemical/isotopic signatures that provide indication of changes in $\mathrm{CO}_{2}$ concentration and/or brine composition, both within the injection zone and immediately above the primary confining zone. In addition to these direct measurements, several indirect geophysical monitoring technologies were included in the monitoring program design such as passive seismic and integrated surface deformation monitoring. Although the FutureGen 2.0 Project was suspended by the U.S. Department of Energy prior to implementation of the monitoring program design, this overview is provided with the hope that other current or future CCS projects will derive benefit from consideration of the approach and monitoring network configuration adopted by the project.
\end{abstract}

Keywords: carbon sequestration; carbon capture and storage; monitoring; MVA; leak detection

\section{Introduction}

The advancement of carbon capture and storage (CCS) technology shows promise for addressing carbon dioxide $\left(\mathrm{CO}_{2}\right)$ emissions and global climate change concerns (White et al., 2003; Gale, 2004; Hepple and Benson, 2005; Bachu, 2008). The objective of the FutureGen 2.0 Project was to demonstrate, at the commercial scale, the technical feasibility of implementing CCS in a deep saline reservoir (Bonneville et al., 2013). Previous modeling studies of large-scale $\mathrm{CO}_{2}$ injection within the Illinois Basin indicated that this reservoir shows promise as a national CCS resource (Birkholzer and Zhou, 2009; Birkholzer et al., 2009; Person et al., 2010). In cooperation with the U.S. Department of Energy (DOE), the FutureGen 2.0 Project partners - the FutureGen Industrial Alliance, Inc. (Alliance) - planned to repower a previously retired oil-fired power plant in Meredosia, Illinois, with oxycombustion technology to capture approximately 1.1 million metric tons (MMT) of $\mathrm{CO}_{2}$ each year, which represents more than 90 percent of the plant's expected carbon emissions. Other emissions, such as sulfur oxides, nitrogen oxides, and mercury, would be reduced to near-zero levels. Using safe and proven pipeline technology, the $\mathrm{CO}_{2}$ would be transported approximately $45 \mathrm{~km}$ to the storage site near Jacksonville, Illinois, and injected into a deep saline reservoir $(\sim 1,200 \mathrm{~m}$ below ground surface) through a network of four horizontal injection wells (Figure 1). 


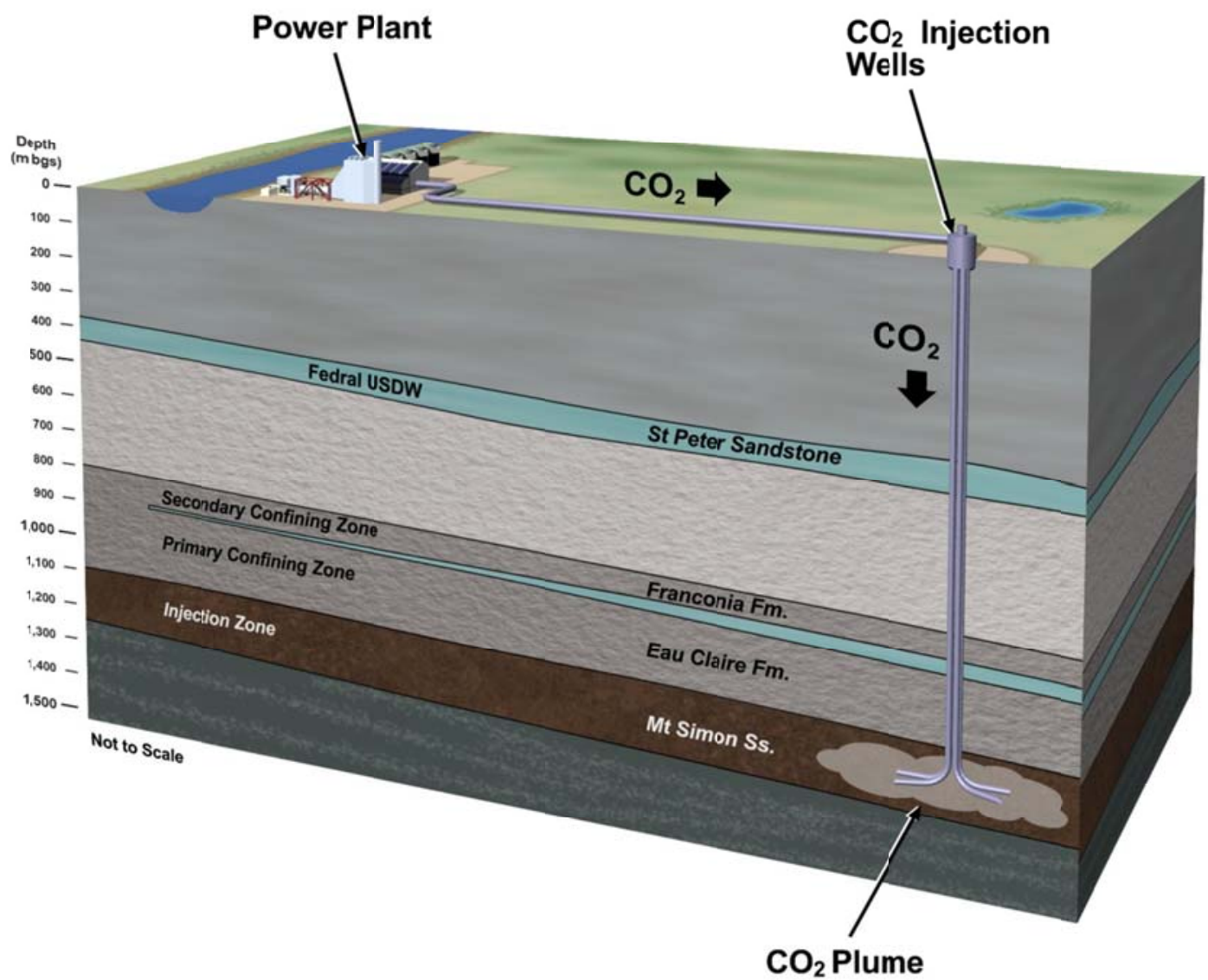

Figure 1. Conceptual diagram of the proposed FutureGen 2.0 CCS project.

To assess storage site performance and meet the regulatory requirements of the Class VI Underground Injection Control (UIC) Program for $\mathrm{CO}_{2}$ Geologic Sequestration, a monitoring program design was developed to track and account for the mass of $\mathrm{CO}_{2}$ injected. This paper provides a summary of the overall monitoring approach adopted by the FutureGen 2.0 Project, and the testing and monitoring activities that the Alliance planned to undertake at its FutureGen 2.0 storage site.

The U.S. Environmental Protection Agency (EPA) has developed a series of guidance documents to promote the development of technically sound CCS monitoring programs and to assure that monitoring activities are performed in accordance with Title 40 of the Code of Federal Regulations (CFR) Sections 146.89, 146.90, and 146.91 (40 CFR $\$ 146.89,146.90$, and 146.91). In addition to the EPA-published testing and monitoring guidance (EPA, 2013), others have published generalized guidance on 1) development of CCS monitoring programs (Chadwick et al., 2008; NETL, 2009, 2012), 2) modeling assessments of $\mathrm{CO}_{2}$ storage and leak detection (White et al., 2005; Birkholzer et al., 2009, 2011; Seto and McRae, 2011; Fahrner et al., 2012; Sun and Nicot, 2012; Jung et al., 2013; Sun et al. 2013), the use of tracers for improved leak detection (Myers et al., 2013), and the application of geophysical technologies to monitoring CCS demonstration sites (Hannis, 2010; Verdon et al., 2013).

A wide range of monitoring tools and techniques have been deployed and tested at a variety of $\mathrm{CO}_{2}$ storage project sites around the world. Current technologies for $\mathrm{CO}_{2}$ monitoring range from direct and indirect measurements focused on the reservoir, to near-surface environmental monitoring. A generalized schematic of the types of monitoring technologies that are relevant to CCS applications is presented in Figure 2. Many available tools are relatively mature, having been developed in the oil and gas industry, and can be readily applied to $\mathrm{CO}_{2}$ monitoring (e.g., direct pressure and temperature monitoring, passive and active seismic monitoring). Other tools and monitoring methodologies are less well developed or require modification and/or procedural change to support CCS monitoring applications (e.g., geochemical monitoring, electrical resistivity methods). Because each $\mathrm{CO}_{2}$ storage site has unique site-specific characteristics, objectives, and requirements, there are unlikely to be a standard 
suite of monitoring technologies or set of established practices for $\mathrm{CO}_{2}$ monitoring that are broadly applicable to all CCS sites (Seto and McRae, 2011; Sun et al., 2013). Therefore, each project must establish a unique monitoring program that addresses regulatory requirements (e.g., Class VI UIC permit requirements) and site-specific risks, in addition to supporting the primary monitoring objectives of the project.

A comprehensive review of existing monitoring programs for CCS demonstration site is not within the scope of this paper. However, information from monitoring program designs from other sites was considered during development of the FutureGen 2.0 monitoring program. Several online sources of information document the status of planned and existing CCS projects located in the United States and internationally. Information is available from several sources. ${ }^{1}$ These sources provide generalized monitoring program attributes for many of the CCS

demonstration projects, but the peer-reviewed literature contains relatively little detail regarding the rationale behind the overall monitoring approach or site-specific design considerations for the various CCS demonstration sites.

Although DOE suspended the FutureGen 2.0 Project prior to implementation of the monitoring program design, it is hoped that the experience and insights gained during development of this design will add to the growing body of peer-reviewed literature and benefit others in the CCS community.

Because the FutureGen 2.0 Project is set at a greenfield site and involves injection into a deep saline reservoir occurring within a sandstone formation, other CCS demonstrations performed in similar settings were of primary interest (e.g., Archer Daniels Midland's Decatur site in Decatur, Illinois; Tenaska's Taylorville site in Christian County, Illinois; American Electric and Power's Mountaineer site in New Haven, West Virginia; the In Salah site at Krechba Field, Algeria; and the Ketzin pilot storage site in Ketzin, Germany). As discussed by Wolaver et al. (2013), monitoring programs for greenfield sites will be inherently different from those for brownfield sites, which are generally associated with enhanced oil, gas, or coal-bed methane recovery (e.g., the DOE's Frio Test Pilot at the Liberty Oil Field, Dayton, Texas; the Southeast Regional Partnership on Carbon Sequestration's (SECARB's) saline reservoir field test at the Cranfield Oil Field in Jackson County, Mississippi; the SECARB Central Appalachian Basin Coal Test in Buchanan County, Virginia; and the $\mathrm{CO}_{2}$-enhanced oil recovery (EOR) project at the Weyburn Oil Field in Saskatchewan, Canada), and thus, are not as applicable to FutureGen 2.0 site conditions.

Although brownfield sites employ many of the same monitoring technologies typically used at greenfield CCS demonstration sites, they can be generally characterized as having numerous active and abandoned hydrocarbon production wells that act as potential release pathways that should be of primary consideration when developing a monitoring strategy Many of these sites have planned for or implemented the use of tracers and near-surface environmental monitoring methodologies, such as atmospheric monitoring, soil-gas and $\mathrm{CO}_{2}$ flux monitoring, and shallow groundwater monitoring (Madsen et al., 2009; Hovorka et al., 2011; Seto and McRae, 2011; Gilliland et al., 2013; Myers et al., 2013; Beaubien et al., 2013). Evaluation and selection of indirect geophysical monitoring methodologies must also consider the differences between greenfield and brownfield site characteristics. For example, injection of supercritical $\mathrm{CO}_{2}\left(\mathrm{scCO}_{2}\right)$ for EOR applications is generally accompanied by simultaneous extraction of hydrocarbon and the net volume change, and the resulting change in reservoir pressure, is typically much smaller than would be expected for a commercial-scale greenfield CCS site. Because the anticipated level of induced seismicity has been previously associated with the net volume of injected fluid in other studies (Zoback and Gorelick, 2012; Verdon et al., 2013; McGarr, 2014), it follows that the potential for increased seismic risk would be a prominent design consideration at greenfield sites where hydrocarbon production is not occurring.

The suite of monitoring technologies selected for implementation as part of a CCS monitoring program must meet both project- and site-specific objectives, along with the requirements mandated by regulators and other local

${ }^{1}$ Global CCS Institute (http://www.globalccsinstitute.com/resources/data/dataset/status-ccs-project-database), IEA Greenhouse Gas Research and Development Program (http://www.co2captureandstorage.info/co2db.php), MIT Carbon Capture and Sequestration Technologies (http://sequestration.mit.edu/), NETL Carbon Capture and Sequestration Database (http://www.netl.doe.gov/technologies/carbon_seq/global/database/index.html), Scottish Center for Carbon Capture (http://www.sccs.org.uk/storage/globalsitesmap.html), Zero $\mathrm{CO}_{2}$ (http://www.zeroco2.no/projects), and Zero Emissions Platform (http://www.zeroemissionsplatform.eu/projects/global-projects.html). 


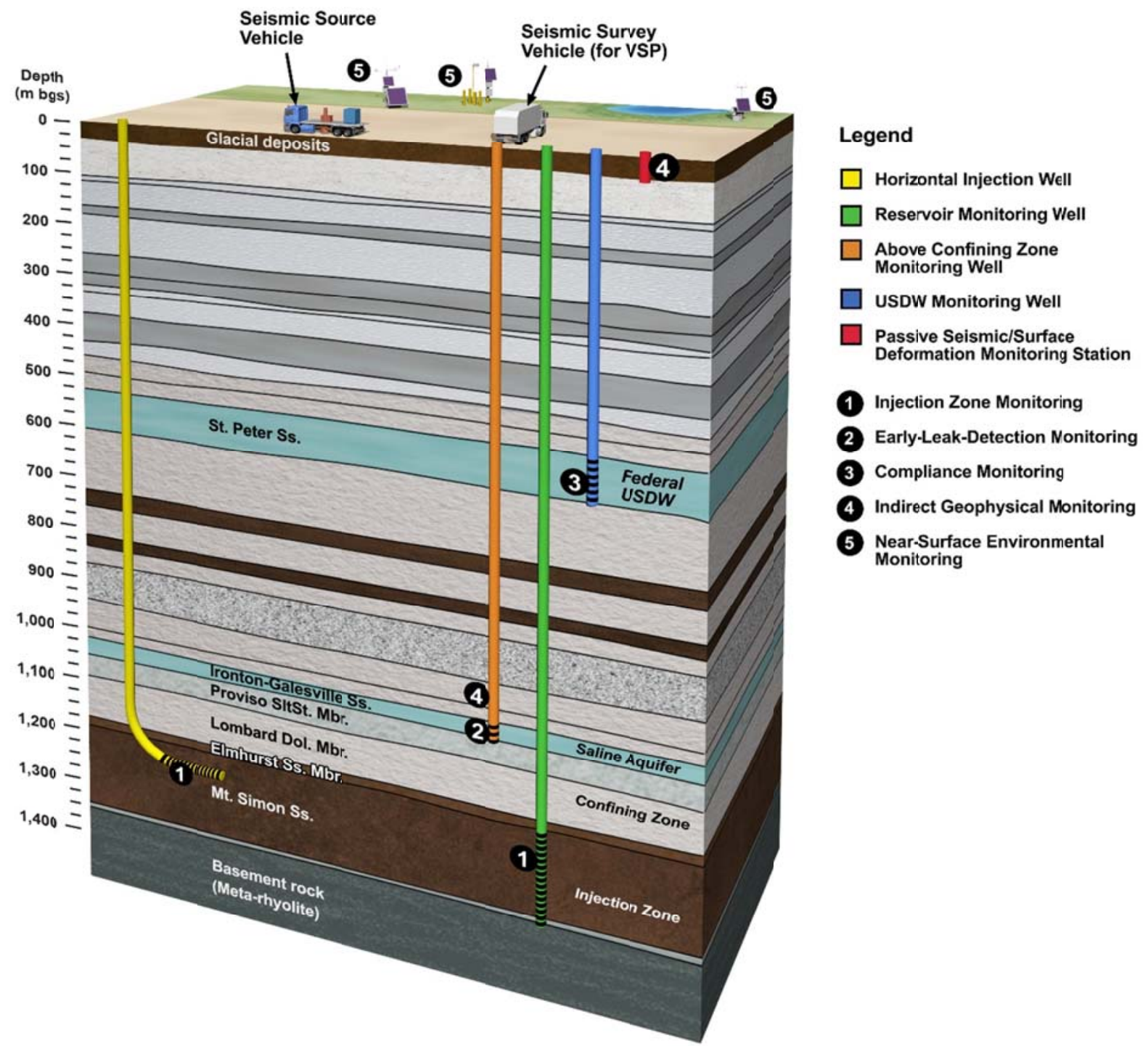

Figure 2. Generalized schematic of monitoring technologies applicable to CCS. Stratigraphy from the proposed FutureGen 2.0 storage site was used in this conceptual diagram to provide site-specific context.

stakeholders. Injection process monitoring, injection-well integrity monitoring, and direct pressure/temperature (and in some cases geochemical) monitoring within the targeted storage reservoir are standard industry practice and are routinely implemented at CCS demonstration sites. Less standardized, owing to the variability in site-specific conditions and overall monitoring philosophy adopted by the various demonstration teams, are the monitoring approaches and methodologies implemented for leak detection, near-surface environmental monitoring, and indirect geophysical monitoring of the development and evolution of the $\mathrm{CO}_{2}$ plume and pressure front.

Few CCS demonstration projects have relied on direct pressure and/or geochemical monitoring immediately above the primary confining zone to provide for improved early-leak-detection capabilities. Two notable exceptions are the Illinois Basin - Decatur Project where a multi-level Westbay well is used to monitor within both the targeted injection interval and the first permeable interval above the caprock (Couëslan et al., 2013) and the SECARB Cranfield site where pressure is monitored $\sim 120 \mathrm{~m}$ above the injection interval in a 60 -year-old dualcompletion monitoring well (Hovorka et al., 2011). Projects have also relied on the deployment of networks of near-surface monitoring technologies to facilitate $\mathrm{CO}_{2}$ leak detection, including shallow groundwater monitoring (Kharaka et al., 2010; Mathieson et al., 2011; Gollakota and McDonald, 2012; Keating et al., 2013; Korose et al., 2013; Gal et al., 2014); soil-gas and $\mathrm{CO}_{2}$ flux monitoring (Locke et al., 2011; Mathieson et al., 2011; Gollakota and 
McDonald, 2012; Romanak et al., 2012; Carman et al., 2013; Korose et al., 2013; Schloemer et al., 2013; Moni and Rasse 2014); atmospheric monitoring (Madsen et al., 2009; Locke et al., 2011; Moni and Rasse, 2014); and remote sensing of vegetative stress (Gollakota and McDonald, 2012; Litynski et al., 2013). Although chemical and isotopic tracers have been used at pilot-scale CCS demonstration sites (Myers et al., 2013), and are more commonly used at enhanced oil and gas recovery sites (Kharaka et al., 2006; Wells et al., 2007; Johnson et al., 2009, 2011a, 2011b), their use has not been widespread at large-scale greenfield CCS demonstration sites. One notable exception is the In Salah $\mathrm{CO}_{2}$ storage site, where perfluorocarbon tracers were used to differentiate the $\mathrm{CO}_{2}$ mass contribution of the various injector wells (Ringrose et al., 2009; Mathieson et al., 2011).

Geophysical methods have been demonstrated at several CCS sites. Passive seismic monitoring is commonly used at CCS sites to monitor for induced seismicity; some examples include the Decatur, Illinois site (Will, 2012), the Midwest Regional Carbon Sequestration Partnership's Michigan site, and the site in Weyburn, Alberta, Canada (Verdon et al., 2013). Surface deformation monitoring has been implemented at a number of $\mathrm{CO}_{2}$ storage sites, including those at Weyburn (Verdon et al., 2013) and Decatur (Finley, 2014). Interferometric synthetic aperture radar (InSAR), a radar-based technique that is capable of measuring millimetre-scale changes in deformation remotely (i.e., by satellite or aircraft), has been used successfully at a commercial $\mathrm{CO}_{2}$ sequestration site at In Salah, Algeria (Vasco et al., 2010) as a means of characterizing surface uplift and migration of the $\mathrm{CO}_{2}$ pressure front, and for identifying the location of reservoir compartmentalization and the presence of a previously unmapped fault under non-vegetated desert conditions. Repeat gravity surveys provide a means of measuring changes in the density/mass of the injected $\mathrm{CO}_{2}$ over time. This technology has been successfully applied to a variety of subsurface injection studies, including carbon sequestration at the Sleipner site in the North Sea (Arts et al., 2008). As with other geophysical methods, the utility of time-lapse gravity for monitoring the injection of $\mathrm{CO}_{2}$ depends on a number of site-specific properties and should be evaluated on a site-by-site basis. Pulsed-neutron capture (PNC) logging has been successfully implemented at a number of carbon sequestration sites, including Nagoaka, Japan (Sakurai et al., 2005); the SECARB site at Cranfield, Mississippi, USA (Butsch et al., 2013); and Ketzin, Germany (Ivanova et al., 2012).

\section{Monitoring Design Basis}

Many factors were considered during development of the monitoring program for the FutureGen 2.0 Project. Four primary design considerations helped guide development of the overall monitoring philosophy and selection of the suite of monitoring technologies that were implemented in the monitoring program design. These design considerations include applicability of the technologies under site-specific conditions, identification and mitigation of the various sources of project risk, assessment of the relative benefits of using co-injected tracers, and assessment of early-leak-detection capabilities. A detailed discussion of these design considerations is provided by Vermeul et al. (2014a and 2014b) and Alliance (2015), and is summarized briefly below.

\subsection{Site Conceptual Model}

The conceptual model for the proposed FutureGen 2.0 storage site was based on both regional and site-specific geologic, geohydrologic, and geochemical information. A detailed discussion of the storage site conceptual model and the site-specific characterization data that were collected to better inform this model is provided in the final project report (Alliance, 2015). In addition to available regional information, the Alliance drilled one stratigraphic borehole at the proposed storage site to support site-specific characterization. During installation of this borehole, a suite of characterization activities were conducted that included geophysical wireline logging, collection and laboratory analysis of core and water samples, a geohydrologic testing program, a geomechanical testing program, and a vertical seismic profiling program. In addition to these downhole characterization activities, surface-based geophysical methods were employed to interrogate the site geology and determine whether large-scale faults or other geologic features were indicated. These methods included two-dimensional seismic-reflection surveys and a gravity survey.

The storage site conceptual model was used to guide development of the FutureGen 2.0 monitoring program. In general, the stratigraphy encountered beneath the proposed storage site was consistent with the regional geologic setting (see Figure 2 for generalized site stratigraphy). The targeted injection zone was contained within an $\sim 190 \mathrm{~m}$ thick sequence of permeable sandstone and was overlain by a confining zone consisting of $\sim 120 \mathrm{~m}$ of lowpermeability dolomites and siltstones. Just above this primary confining zone was a permeable unit (Ironton- 
Galesville Sandstone) that was identified as an early-leak-detection monitoring interval. This monitoring interval was an important component of the overall monitoring approach because it provided for an early-leak-detection capability and helped to facilitate both regulatory and public acceptance of the monitoring program. In addition to this early-leak-detection monitoring interval, the design includes a monitoring well installed within the Saint Peter Sandstone Formation, the designated lowermost underground source of drinking water (USDW) at the site. Characterization data indicated that between these two above-confining-zone monitoring intervals there were 1) multiple secondary confining zones and 2) the Potosi Formation, which is a high-permeability karstic dolomite that contains vuggy porosity and would be expected to act as a thief zone in the event leakage did occur at the site. The monitoring well network design, which included direct monitoring in the injection zone, immediately above the primary confining zone, and in the lowermost USDW aquifer, was informed by the site-specific characterization data collected by the project.

Surface-based seismic-reflection surveys are an industry standard approach for imaging the subsurface and were used to help characterize the FutureGen 2.0 site. Although these surveys were useful for geologic characterization and showed no indication of large-offset faults beneath the site, the quality of the seismic data was generally poor due to unfavourable site conditions and thus was insufficient to rule out the presence of small-scale faults/fracture zones. Although the presence of small-scale features could not be disproved by these surveys, it should be noted that the proposed site is not located in a seismically active part of the state and has no geologic faults or fracture zones shown on the structural geology map published by the Illinois State Geological Survey (ISGS). Based on an analysis of site seismic-reflection data sets and a modeling analysis performed to investigate the efficacy of using seismic methods for $\mathrm{CO}_{2}$ monitoring under expected site conditions, it was determined that seismic-reflection-based methods would not be an effective indirect monitoring approach for tracking the spatial extent of the $\mathrm{CO}_{2}$ plume (Vermeul et al., 2015a), and thus it was not included in the monitoring program design.

\subsection{Assessment of Project Risk}

A quantitative risk assessment of all identified sources of CCS implementation risk was not within the scope of the FutureGen 2.0 project. This planned commercial-scale implementation of CCS was supported in part by an industrial alliance and there was no programmatic support for conducting this type of quantitative assessment. Identified sources of project risk (Table 1) were considered and qualitatively assessed. Findings from this qualitative assessment were used to guide selection of technologies included in the monitoring program design. However, in addition to these sources of project risk, other factors such as monitoring systems cost (both capital and operational costs), site access restrictions, and landowner acceptance played a major role in the selection and siting of the various monitoring infrastructure. Due to the agricultural setting of the proposed FutureGen 2.0 storage site and the programmatic objective of limiting impacts on local landowners, lands available for siting of monitoring infrastructure were limited. Well sites and geophysical monitoring locations identified in the monitoring program design were based on the predicted extent and distribution of the $\mathrm{CO}_{2}$ plume and pressure front, but placement of these monitoring locations was largely dictated by the need to avoid productive farmland, and thus siting options were limited to areas not under cultivation or along the edges of cultivated fields that facilitated easy access to existing roadways. These land restrictions, along with the limited amount of regional and site-specific characterization data available to support a risk assessment, precluded the use of quantitative risk assessment and/or systematic optimization of monitoring infrastructure locations as a primary basis for the monitoring program design. Therefore, a qualitative assessment approach was adopted.

As indicated in Table 1, the most significant project risk was expected to be associated with the potential for injection-related induced seismicity. Although most induced seismicity would not be expected to cause public concern or otherwise affect storage operations, the potential for larger events must be considered. A passive seismic monitoring network is needed to accurately determine the locations, magnitudes, and focal mechanisms of injectioninduced seismic events. The primary objectives of seismic monitoring are to 1) address public and stakeholder concerns related to induced seismicity, 2) estimate the spatial extent of the pressure front from the distribution of seismic events, and 3) support assessment of confining zone integrity. Once a seismic event has been identified, a decision must be made regarding the level of impact a given event could have on storage site operations, whether a response is required, and if so, what the response will be. The developed decision and response framework consisted of an automated determination of event location and magnitude, followed by an alert for a technical review in order to reduce the likelihood of false positives. Identification of events with sufficient magnitude or that are located in a sensitive area (e.g., within the confining zone) would be used as input for decisions that guide the 
Table 1. Sources of Project Risk Considered in the Monitoring Program Design

\begin{tabular}{|l|c|l|l|}
\hline \multicolumn{1}{|c|}{ Project Risk } & Level & \multicolumn{1}{|c|}{ Rationale } & \multicolumn{1}{c|}{ Risk Mitigation } \\
\hline $\begin{array}{l}\text { Diffuse leakage through } \\
\text { confining zone }\end{array}$ & Low & $\begin{array}{l}\text { Regional and site-specific } \\
\text { information indicated a competent } \\
\text { confining zone }\end{array}$ & $\begin{array}{l}\text { Early-leak detection, above- } \\
\text { confining-zone (ACZ) monitoring }\end{array}$ \\
\hline $\begin{array}{l}\text { Geologic features (faults, } \\
\text { fractures) that compromise } \\
\text { confining zone }\end{array}$ & Low & $\begin{array}{l}\text { Regional and site-specific } \\
\text { information identified no geologic } \\
\text { features of concern }\end{array}$ & $\begin{array}{l}\text { Passive seismic monitoring to } \\
\text { identify and limit induced } \\
\text { seismicity }\end{array}$ \\
\hline $\begin{array}{l}\text { Abandoned wells that } \\
\text { penetrate confining zone }\end{array}$ & Low & $\begin{array}{l}\text { State and local records indicated } \\
\text { no abandoned wells in the vicinity } \\
\text { that penetrate the confining zone. }\end{array}$ & None required \\
\hline $\begin{array}{l}\text { Project-installed wells that } \\
\text { penetrate confining zone }\end{array}$ & Mod & $\begin{array}{l}\text { Injection wells and injection-zone } \\
\text { monitoring wells would penetrate } \\
\text { the confining zone; this risk must } \\
\text { be weighed in relation to the need } \\
\text { for direct reservoir monitoring }\end{array}$ & $\begin{array}{l}\text { Best practices well construction, } \\
\text { mechanical integrity testing, ACZ } \\
\text { monitoring near wells that } \\
\text { penetrate confining zone }\end{array}$ \\
\hline $\begin{array}{l}\text { Reservoir heterogeneity } \\
\text { results in a CO } \mathrm{CO}_{2} \text { plume that } \\
\text { extends beyond procured } \\
\text { pore space }\end{array}$ & Mod & $\begin{array}{l}\text { Programmatic risk that could } \\
\text { have legal and regulatory } \\
\text { implications }\end{array}$ & $\begin{array}{l}\text { Injection-zone monitoring, } \\
\text { integrated deformation monitoring, } \\
\text { adaptive monitoring strategy }\end{array}$ \\
\hline $\begin{array}{l}\text { Induced seismicity } \\
\text { High }\end{array}$ & $\begin{array}{l}\text { Stakeholder and local landowner } \\
\text { concern, potential indicator of } \\
\text { compromised confining zone }\end{array}$ & $\begin{array}{l}\text { Passive seismic monitoring } \\
\text { program }\end{array}$ \\
\hline
\end{tabular}

adaptive strategy. Seismic events that affect the operations of $\mathrm{CO}_{2}$ injection can be divided into two groups/tiers: 1) events that create felt seismicity at the surface and may lead to public concern or structural damage, and 2) events not included in group one, but that would lead to concern about the integrity of the confining zone.

The operational protocol for responding to events in group one (Tier I) adopted a "traffic light" approach (modified after Zoback 2012; National Research Council, 2012) that uses three operational states:

- Green: Continue normal operations unless injection-related seismicity is observed with magnitudes greater than $\mathrm{M}=2$.

- Yellow: Injection-related seismic events are observed with magnitude $2<\mathrm{M}<4$. The injection rate would be lowered and the relationship between rate and seismicity would be evaluated to guide mitigation procedures, including reduced operational flow rates.

- Red: Magnitude 4 or greater seismic events are observed. Injection operations would stop and an evaluation would be performed to determine the source and cause of the ground motion.

Tier II operational responses to an event or collection of events that indicate a potential for impacts on primary confining zone integrity could include things such as supplemental adaptive monitoring activities, injection rate reduction in one or more injection wells, or pressure reduction through brine extraction.

Two other identified sources of project risk include asymmetric, heterogeneous development of the $\mathrm{CO}_{2}$ plume and leakage associated with project-installed wells. The predicted lateral extent of the $\mathrm{CO}_{2}$ plume, which was simulated using a numerical model that incorporated available regional and site-specific characterization data, was used to design the monitoring network. Although this idealized plume shape and extent were used in the design, it was recognized that asymmetric plume development was possible. The monitoring network design addressed this prediction uncertainty in part by adopting an "adaptive" or "observational" monitoring approach, i.e., the monitoring approach is adjusted as needed based on observed monitoring and updated modeling results (Hudak and Loaiciga, 1992; Belcher and Sichelstiel, 1995; Siegrist et al., 2011). This approach would include the option to install additional wells in out-years to verify $\mathrm{CO}_{2}$ plume and pressure-front evolution and/or evaluate leakage potential. If 
plume development were to proceed in a fashion that would result in exceedance of the procured pore space allocations, operational and/or contractual modifications would be required to facilitate further $\mathrm{CO}_{2}$ injection. Leakage associated with project-installed wells that penetrate the primary confining zone was also considered in the assessment, as was the importance of being able to track the distribution and lateral extent of the tracer plume and pressure front within the targeted injection zone. This leakage risk would be mitigated in part through implementation of best practices well installation and completion techniques and through continued mechanical integrity testing of all wells penetrating the confining zone throughout the life of the project. To further mitigate this risk, the monitoring program design incorporates early-leak-detection monitoring wells that monitor the zone immediately above the confining zone and are located proximal to project-installed wells that penetrate the primary confining zone. These wells would be used to monitor for indicators of $\mathrm{CO}_{2}$ and/or brine leakage.

The risk associated leakage through natural pathways in the confining zone was limited to a large extent by the geologic conditions present at the proposed FutureGen 2.0 storage site. The principal geologic structure in this area is the very broad Sangamon Arch. In the vicinity of the storage site, no mapped faults and no known karst or fracture systems are associated with this arch structure (Whiting and Stevenson 1965; Kolata and Nelson 1991). Based on this regional information and reflection seismic surveys conducted during characterization of the storage site (Bonneville et al., 2013; Alliance, 2015), the risk associated with loss of confining zone integrity at the proposed FutureGen 2.0 storage site was considered to be low. Surface-based seismic-reflection surveys performed at the site indicated a thick sequence of Paleozoic-aged rocks and provided no substantial evidence for the presence of faults or large changes in formation thickness across the study area. The targeted injection zone (Mount Simon Sandstone) is overlain by the Eau Claire Formation (Figure 1), a thick regional confining zone of low permeability that overlies the Elmhurst Sandstone Member. The Franconia Dolomite and Davis Member also serves as a secondary confining zone for additional protection of USDWs.

\subsection{Tracers}

During development of the FutureGen 2.0 monitoring program, the relative benefit of using intrinsic geochemical signals versus co-injected tracers for improved transport monitoring and early-leak detection was evaluated (Amonette et al., 2014). The first of these approaches involves measurements of intrinsic geochemical signals, such as changes in $\mathrm{pH}$, dissolved metals, and isotopic signature. This approach relies on chemical interactions between the stored $\mathrm{CO}_{2}$ and the subsurface, or on innate differences in the isotopic chemistry of stored and natural $\mathrm{CO}_{2}$, to produce compositional changes in fluids that can be interpreted as transport and/or leakage signals. An alternative approach involves the co-injection of a tracer compound along with the $\mathrm{CO}_{2}$.

The types of intrinsic geochemical signals that would be expected to result from interactions between injected $\mathrm{CO}_{2}$ and the reservoir (and aquifers above the confining zone if a leak has occurred) are associated with changes in the chemical and isotopic composition of the groundwater (Kharaka et al., 2006; Keating et al., 2013; Moni and Rasse, 2014; Vermeul et al., 2014a). Chemical changes include increases in the concentration of total dissolved solids, dissolved trace metals, noble gases, and carbonate species, and a decrease in the $\mathrm{pH}$. If the $\mathrm{CO}_{2}$ injection resulted in compositional changes in the saline reservoir fluids, either as the result of transport processes occurring within the reservoir or leakage to overlying aquifers, changes in the concentrations of sodium and chloride and measured specific conductance would be expected. If a leakage response involved the migration of free-phase $\mathrm{CO}_{2}$ (i.e., $\mathrm{CO}_{2}$ not dissolved in aquifer fluids) into monitoring intervals above the primary confining zone, a resulting change in specific conductance (i.e., decrease) would also be expected.

Monitoring for isotopic change relies primarily on detecting differences between the isotopic composition of carbon $\left({ }^{14} \mathrm{C},{ }^{13} \mathrm{C}\right.$, and $\left.{ }^{12} \mathrm{C}\right)$ present in the injectate and the pre-existing carbon in the reservoir and overlying aquifer fluids. Isotopic measurements of other nuclides such as oxygen $\left({ }^{18} \mathrm{O},{ }^{16} \mathrm{O}\right)$ can also be of value, particularly when entrained $\mathrm{O}_{2}$ is present in the injectate. Isotopic shifts in noble gas composition $\left(\right.$ e.g. $.{ }^{3} \mathrm{He} /{ }^{4} \mathrm{He},{ }^{20} \mathrm{Ne} /{ }^{22} \mathrm{Ne},{ }^{21} \mathrm{Ne} /{ }^{22} \mathrm{Ne}$, $\left.{ }^{38} \mathrm{Ar} /{ }^{40} \mathrm{Ar}\right)$ also occur in response to the release of radiogenic isotopes $\left({ }^{4} \mathrm{He},{ }^{21} \mathrm{Ne},{ }^{22} \mathrm{Ne}\right.$, and $\left.{ }^{40} \mathrm{Ar}\right)$ trapped in minerals that are subsequently dissolved by contact with $\mathrm{CO}_{2}$. Recently, field measurements of ${ }^{13} \mathrm{C} /{ }^{12} \mathrm{C}$ ratios in $\mathrm{CO}_{2}$ and methane isolated from groundwater or in soil-gas have become practical with the advent of off-axis integrated cavity output laser spectrometers (McAlexander et al., 2011; Mortazavi et al., 2013), and there is some hope that the sensitivity can be enhanced to allow ${ }^{14} \mathrm{C} /{ }^{12} \mathrm{C}$ ratios to be determined in the field as well (Marino et al., 2011). Differences in the carbon isotopic composition between the injection and native fluids, and that of the $\mathrm{CO}_{2}$ injection stream, may provide an isotopic signature that could be used as an indicator of the presence of injected $\mathrm{CO}_{2}$. 
Two general classes of aqueous tracers, hydrophobic and hydrophilic, can be co-injected with $\mathrm{CO}_{2}$. The hydrophobic tracers are generally perfluorinated compounds such as perfluoro-1,2-dimethylcyclohexane (PDCH), perfluorotrimethyl-cyclohexane (PTCH), and perfluorodimethyl-cyclobutane (PDCB). Each of these perfluorinated tracer (PFT) compounds is highly soluble in $\mathrm{scCO}_{2}$ and has been previously injected with $\mathrm{CO}_{2}$ in field studies (e.g., Wells et al., 2007, 2010, 2013). Subsequent transport of $\mathrm{CO}_{2}$ and PFTs varies significantly, however, because of the widely disparate solubilities of these compounds in water. In contrast to $\mathrm{CO}_{2}$, PFTs have very limited aqueous solubilities and rapidly partition into hydrophobic solid phases (e.g., coal seams, soil organic matter, very dry clay minerals) or into the gas phase at aqueous/gaseous phase boundaries. Gas-phase partitioning of PFTs is generally helpful to monitoring, because it means that, in most instances, PFTs can provide an early warning signal (Senum et al., 1997; Wells et al., 2007; Zhong et al., 2014). Another class of hydrophobic tracers that has been used is $\mathrm{SF}_{6}$ and various substituted versions (e.g., $\mathrm{SF}_{5} \mathrm{CF}_{3}$; Matter et al., 2011). These behave similarly to PFTs, although they are slightly less prone to interactions with sediment surfaces because of their compact size (Zhong et al., 2014).

Because, like $\mathrm{CO}_{2}$, they are reasonably soluble in water, hydrophilic tracers avoid some of the differential transport issues associated with the hydrophobic tracers. Examples of hydrophilic tracers include naphthalene sulfonates such as 2-naphthalene sulfonate, 2,7-naphthalene sulfonate, and 1,3,6-naphthalene trisulfonate (Rose et al., 2001), and fluorinated benzoic acids such as pentafluorobenzoic acid (PFBA), 2,6-difluorobenzoic acid, and 2,3difluorobenzoic acid (Stetzenbach et al., 1982; Flury and Wai, 2003). These tracers have limited volatility so they are measured as aqueous constituents. However, they also have significantly greater affinities for hydrophobic solid phases than does $\mathrm{CO}_{2}$, and thus some transport retardation would be expected in sediments that have high organicmatter contents.

Based on the current understanding of geochemical conditions for the injection zone and ACZ monitoring intervals at the proposed FutureGen 2.0 storage site, the intrinsic signals approach would be expected to provide the required sensitivity to support a viable transport assessment and early-leak-detection capability. Aside from unambiguous identification of potential leakage signals, little additional information for assessment purposes would be gained from the co-injection of aqueous tracers. Tracers are generally used to interrogate the subsurface during site characterization activities or as a means of tracking injectate migration when the signal provided by the injection solution is difficult to detect. For the case of commercial-scale $\mathrm{scCO}_{2}$ injection at a greenfield site, identifying the first arrival of the injectate should not represent a significant technical challenge. In addition, limitations associated with the use of co-injected aqueous tracers need to be considered. From a brine-migration perspective, an aqueous tracer would be most useful if it were added to the injection zone prior to the start of $\mathrm{CO}_{2}$ injection so that it was present within the reservoir prior to the start of $\mathrm{CO}_{2}$ injection, otherwise the incremental improvement in earlyleak-detection capability would be relatively small. From a $\mathrm{CO}_{2}$ leak-detection perspective, uncertainties in the relative transport properties of the aqueous tracers and $\mathrm{CO}_{2}$ would need to be considered.

\subsection{Assessment of Early-Leak-Detection Capabilities}

A modeling assessment was conducted to evaluate the potential for water-quality impacts associated with $\mathrm{scCO}_{2}$ and/or brine leakage resulting from $\mathrm{scCO}_{2}$ storage operations. The model was developed to be independent of a project-developed reservoir model that was used to simulate $\mathrm{CO}_{2}$ injection and storage processes and to make predictions of the spatial and temporal evolution of the $\mathrm{CO}_{2}$ plume. The leak-detection modeling effort did not simulate confining zone discontinuities, faults, or failure scenarios; instead it focused on evaluation of theoretical leakage scenarios based on specified rates of leakage. This preliminary assessment of early-leak-detection capabilities focused on the first permeable interval (Ironton Sandstone) above the primary confining zone (Figure 2) and considered both pressure and geochemical responses. Results from this study were used to inform the earlyleak-detection monitoring design. A more detailed discussion of this assessment, including a description of the modeling approach and comparison of results from the various scenarios evaluated, is provided by Vermeul et al. (2014a) and Williams et al. (2014).

The numerical model used to support this assessment was implemented using the STOMP-CO2 simulator (White et al., 2012). The model domain extends from the bottom of the Ironton Sandstone, which is the first permeable unit above the primary confining zone, to just above the St. Peter Sandstone (Figure 2). The hydrostratigraphy for the model domain was derived from a PETREL solid Earth model of the FutureGen 2.0 storage site (Alliance, 2013). The solid Earth model is based on characterization data obtained from the initial stratigraphic borehole installed at 
the FutureGen 2.0 storage site and numerous other wells in the Illinois Basin. Available site-specific characterization data used to parameterize the model were limited because the focus of the initial stratigraphic borehole drilled at the FutureGen 2.0 site was on characterization of the injection zone (Mount Simon Sandstone and Elmhurst Member of the Eau Claire Formation) and primary confining zone (Proviso and Lombard Members of the Eau Claire Formation). A detailed discussion of model implementation, including model grid discretization and resolution, material properties, and boundary conditions is provided by Vermeul et al. (2014).

A series of leakage scenarios were evaluated that approximate leaks of different magnitudes from an artificial penetration or some other localized source of leakage. These initial scoping-level leakage scenarios assumed $1 \%$ of the total planned $\mathrm{scCO}_{2}$ injection mass (22 MMT) was leaked (0.22 MMT) over three different time periods as follows:

- $1 \%$ of total injected mass leaked over 20 years $(0.011 \mathrm{MMT} / \mathrm{yr})$

- $1 \%$ of total injected mass leaked over 100 years $(0.0022 \mathrm{MMT} / \mathrm{yr})$

- $1 \%$ of total injected mass leaked over 500 years $(0.00044 \mathrm{MMT} / \mathrm{yr})$.

In addition, a 20 -year brine leakage case was simulated with the brine volume equivalent to the $1 \% \mathrm{scCO}_{2}$ volume. Pressure and geochemical responses for all cases were evaluated at three different lateral distances from the point of leakage (approximately $24 \mathrm{~m}, 140 \mathrm{~m}$, and $290 \mathrm{~m}$ ) and at two different depths (the base and top of the Ironton Formation).

Results from this preliminary modeling evaluation demonstrate acceptable leak-detection sensitivities for the various leak-detection signals and leakage scenarios tested. A joint evaluation of both the $\mathrm{scCO}_{2}$ and brine simulations shows that pressure is likely to be the earliest indicator of leakage, given the rapid pressure responses seen for the 20-, 100-, and 500-year scenarios. Accounting for the accuracy and resolution of the pressure sensors specified in the monitoring program design (1.4 and $0.34 \mathrm{kPa}$, respectively), simulation results indicate that a pressure response would be detected within a week for all of the 20- and 100-year leakage scenarios, at all of the distances and at both depth intervals (i.e., top and bottom of the Ironton) evaluated. Pressure responses above the lowest threshold value $(1.4 \mathrm{kPa}$ ) and within $\sim 140 \mathrm{~m}$ from the leak location generally respond quickly, from essentially instantaneously to within 24 hours of the start of leakage. Higher threshold pressures and more distal locations take longer for detection and in some cases may not be detected at all. For the 500-year leakage scenario, higher resolution equipment may be needed for pressure detection, given that the only pressure threshold exceeded was $1.4 \mathrm{kPa}$ for any of the distances and depths evaluated.

The model was also used to evaluate transport response for $\mathrm{CO}_{2}$ and a theoretical conservative tracer (for the brine case), and to predict arrival detection times under various detection threshold criteria. As expected, the simulated geochemical signals were much more localized and took much longer to develop than the pressure responses. In addition, because of the buoyancy effect associated with $\mathrm{scCO}_{2}$ migration, early-leak-detection monitoring for these leakage scenarios is best achieved through upper zone monitoring (see Figure 3 and Figure 4), particularly as monitoring distances from the leakage source increase. No geochemical signals for either the $\mathrm{scCO}_{2}$ or brine simulations occurred in less than a day, and arrivals generally occurred on timescales ranging from months to years. At the closest lateral monitoring location $(\sim 24 \mathrm{~m})$, a geochemical arrival response was predicted to occur within 2 years for all of the $\mathrm{scCO}_{2}$ leakage cases considered. Conservative tracer arrival in the brine leakage case (Figure 5) was predicted to occur within a month at the bottom of the Ironton and within 5 years at the top (i.e., the opposite response from that observed for the $\mathrm{scCO}_{2}$ leakage cases, which are affected by $\mathrm{scCO}_{2}$ buoyancy). The geochemical arrival response was less pronounced at more distal locations. For the largest $\mathrm{scCO}_{2}$ leakage rate case (20-year leakage), $\mathrm{CO}_{2}$ arrival in the upper zone was predicted to occur within 2 years at the $\sim 140 \mathrm{~m}$ lateral distance and within 10 years at the $\sim 290 \mathrm{~m}$ lateral distance. 


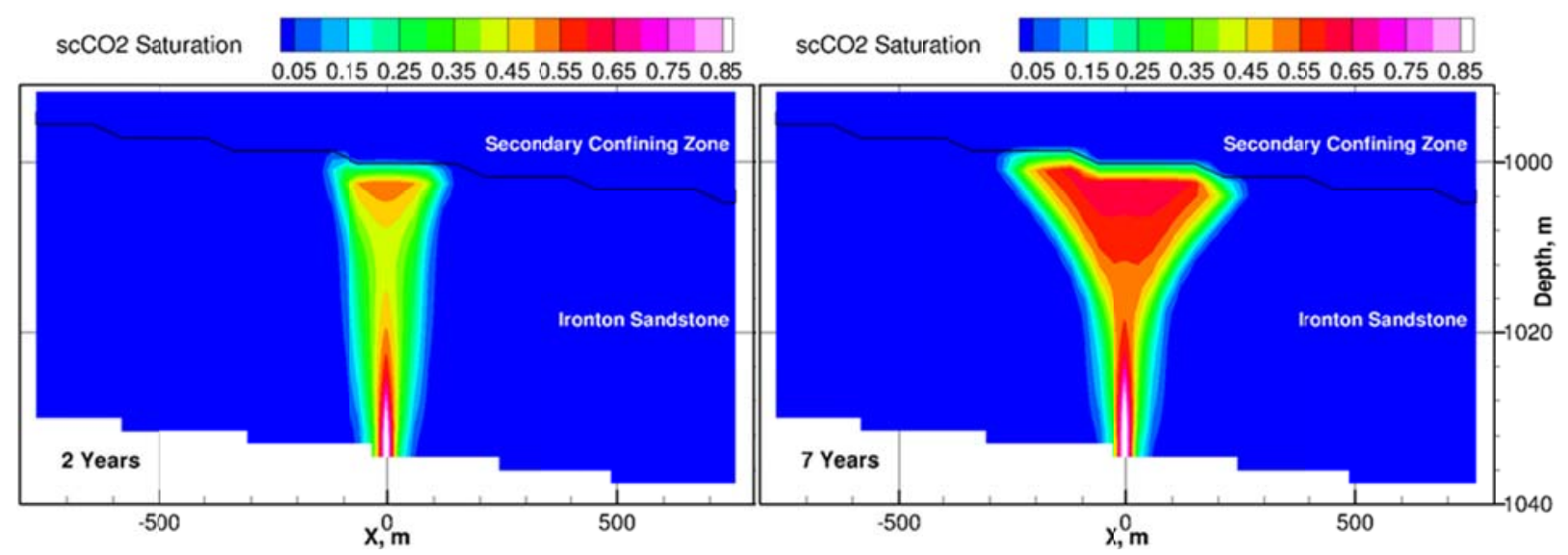

Figure 3. Simulated $\mathrm{scCO}_{2}$ saturations at 2 years (left) and 7 years (right) for the 20 -year $\mathrm{scCO}_{2}$ leakage case.

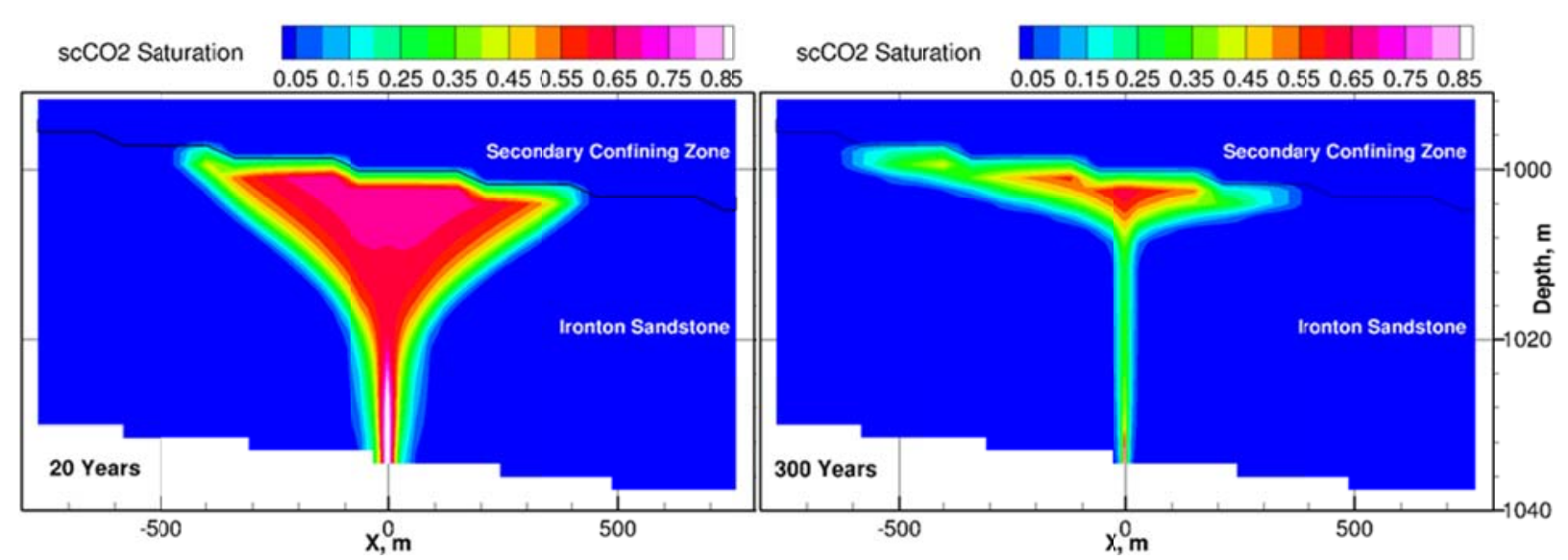

Figure 4. Simulated $\mathrm{scCO}_{2}$ saturations at 20 years for the 20 -year $\mathrm{scCO}_{2}$ leakage case (left) and 300 years for the 500 -year $\mathrm{scCO}_{2}$ leakage case (right).

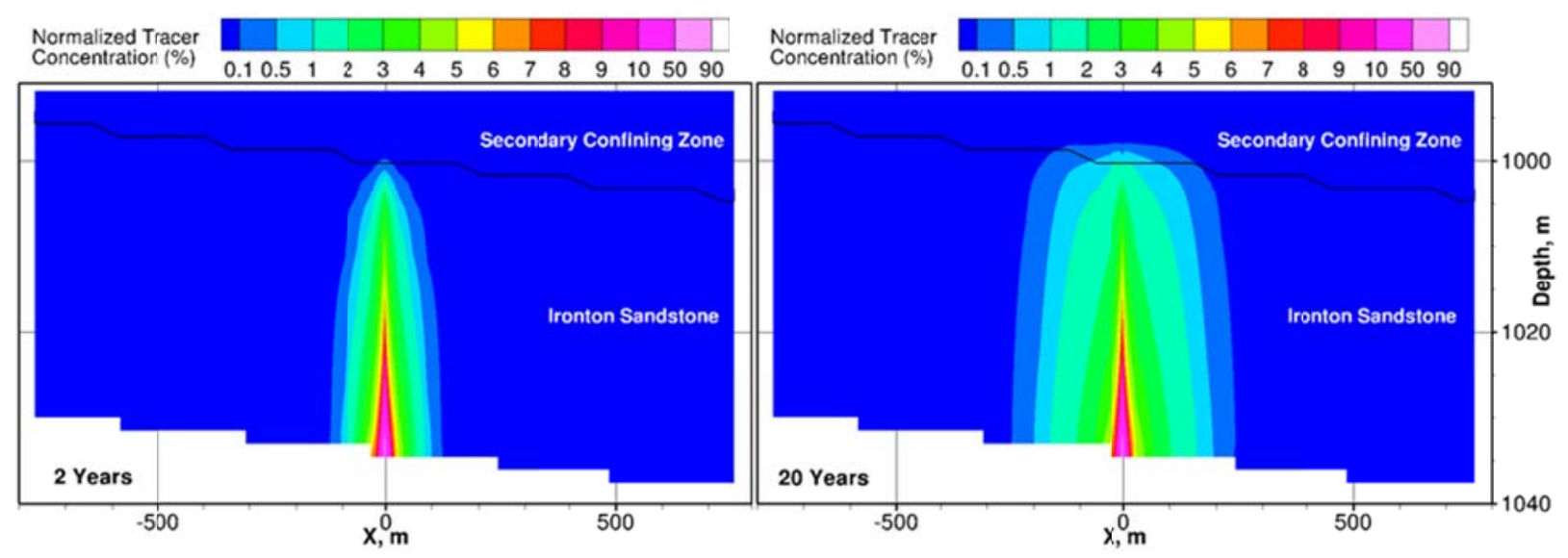

Figure 5. Simulated tracer concentrations at 2 years (left) and 20 years (right) for the 20 -year brine leakage case.

\section{Monitoring Approach}

The FutureGen 2.0 monitoring infrastructure design includes a network of deep monitoring wells and a surfacebased network of combined passive seismic/surface deformation monitoring stations. The $\mathrm{CO}_{2}$ injection stream is continuously monitored as part of the instrumentation and control systems incorporated into the FutureGen 2.0 
design; injection stream monitoring also would include periodic collection and analysis of grab samples to track $\mathrm{CO}_{2}$ composition and purity. A summary of the monitoring technologies that would be implemented under this design and the measurement frequencies for the various phases of the project are provided in Table 2. Additional information on monitoring program analytical requirements (e.g., detection limits, precision/accuracy) are provided by Vermeul et al. (2014b). This monitoring program design was reviewed by the EPA and accepted as the monitoring basis for issuance of a Class VI UIC permit.

The monitoring program design relies on a comprehensive suite of geochemical and isotopic analyses that are performed on fluid samples collected from the reservoir and overlying monitoring intervals. These analytical results are used to characterize baseline geochemistry and provide a metric for comparison during operational phases of the project. A primary design consideration is minimizing lifecycle cost without sacrificing the ability to detect a leak. As a result, only select parameters measured during the baseline monitoring period would be routinely measured during operational phases of the project. Indicator parameters such as specific conductance, $\mathrm{pH}$, and temperature would be used to the extent possible to inform the monitoring program. Once baseline conditions and early $\mathrm{CO}_{2}$ arrival responses have been established, any observed relationships between analytical measurements and indicator parameters would be used to guide less frequent aqueous sample collection in later years.

If a significant $\mathrm{CO}_{2}$ leakage response were detected that could be attributed to injection operations, a modeling evaluation would be used to assess the magnitude of containment loss and make bounding predictions regarding the potential for $\mathrm{CO}_{2}$ migration above the confining zone, including possible impacts on shallower intervals, and ultimately, the potential for adverse impacts on USDW aquifers or other ecological receptors. Observed and simulated arrival responses at the early-leak-detection wells and shallower monitoring locations would be compared throughout the life of the project and results would be used to calibrate and verify the model, and improve its predictive capability for assessing the long-term environmental impacts of fugitive $\mathrm{CO}_{2}$. If early-leak-detection monitoring were to indicate that primary confining zone leakage had occurred, a comprehensive near-surfacemonitoring program would be evaluated and, if warranted, activated to fully assess environmental impacts relative to previously established baseline conditions.

\section{Monitoring Network Summary}

The monitoring network design is based on the Alliance's conceptual understanding of the site and predictive simulations of injected $\mathrm{CO}_{2}$ fate and transport. The model used in the design analysis was parameterized based on site-specific characterization data collected from the initial stratigraphic borehole and reflection seismic surveys conducted at the FutureGen 2.0 storage site (Alliance, 2012). The network design also considered other available regional data, including the effects of structural dip, regional groundwater flow conditions, and the potential for heterogeneities or horizontal/vertical anisotropy within the injection zone and overburden materials (Alliance, 2013; Vermeul et al., 2014a).

\subsection{Monitoring Well Network Design}

The monitoring well network design (Figure 6), which includes both injection-zone monitoring wells and monitoring wells installed above the primary confining zone, is configured to detect leakage from the reservoir as soon after the first occurrence as possible. Two aquifers above the primary confining zone are monitored, including the aquifer immediately above the confining zone (Ironton Sandstone) and the St. Peter Sandstone, which is separated from the Ironton by several carbonate and sandstone formations and is considered to be the lowermost USDW at the site (see Figure 7). Direct monitoring of the lowermost USDW aquifer is a regulatory requirement and is a primary objective of the monitoring program design. Well designs also include instrumentation to detect changes in the stress regime (via pressure in all wells and microseismicity in selected wells) to avoid overpressurization within the injection and confining zones that could compromise sequestration performance. The monitoring well network design includes two wells (SLR1 and SLR2) within the injection zone (Elmhurst/Mount Simon Sandstones), two wells (ACZ1 and ACZ2) within the first permeable interval immediately above the primary confining zone (Ironton Sandstone), and one well (USDW1) within the designated lowermost USDW (St. Peter Sandstone). Proposed well locations are shown in Figure 6 and a hydrogeologic cross section illustrating the relative position and depth interval of the various wells is shown in Figure 7. These wells would be used to continuously and directly monitor for changes in fluid pressure, temperature, and specific conductance $(\mathrm{P} / \mathrm{T} / \mathrm{SpC})$, and would be routinely sampled to monitor for changes in aqueous chemistry. Measurements at these locations would be compared with numerical model predictions and used to calibrate the model as needed. 
Table 2. Monitoring methodologies implemented in the FutureGen 2.0 monitoring program design.

\begin{tabular}{|c|c|c|c|c|c|c|}
\hline \multirow[b]{2}{*}{$\begin{array}{l}\text { Monitoring } \\
\text { Category }\end{array}$} & \multirow[b]{2}{*}{$\begin{array}{l}\text { Monitoring } \\
\text { Method }\end{array}$} & \multicolumn{3}{|c|}{ DOE Active Phase } & \multicolumn{2}{|c|}{ Commercial Phase } \\
\hline & & $\begin{array}{c}\text { Baseline } \\
3 \mathrm{yr}\end{array}$ & $\begin{array}{c}\text { Injection } \\
\text { (Startup) } \\
\sim 3 \mathrm{yr} \\
\end{array}$ & $\begin{array}{l}\text { Injection } \\
\sim 2 \mathrm{yr} \\
\end{array}$ & $\begin{array}{c}\text { Injection } \\
\sim 15 \mathrm{yr} \\
\end{array}$ & $\begin{array}{c}\text { Post- } \\
\text { Injection } \\
50 \mathrm{yr} \\
\end{array}$ \\
\hline $\begin{array}{l}\mathrm{CO}_{2} \text { Injection } \\
\text { Stream Sampling } \\
\text { and Analysis }\end{array}$ & $\begin{array}{l}\text { Grab sampling and } \\
\text { analysis }\end{array}$ & $\begin{array}{l}3 \text { events, during } \\
\text { commissioning }\end{array}$ & Quarterly & Quarterly & Quarterly & NA \\
\hline $\begin{array}{l}\mathrm{CO}_{2} \text { Injection } \\
\text { Stream } \\
\text { Monitoring }\end{array}$ & $\begin{array}{l}\text { Continuous monitoring } \\
\text { of injection process } \\
\text { (injection rate, pressure, } \\
\text { and temperature; annulus } \\
\text { pressure and volume) }\end{array}$ & NA & Continuous & Continuous & Continuous & NA \\
\hline $\begin{array}{l}\text { Corrosion } \\
\text { Monitoring }\end{array}$ & $\begin{array}{l}\text { Corrosion coupon } \\
\text { monitoring of injection- } \\
\text { well materials }\end{array}$ & NA & Quarterly & Quarterly & Quarterly & NA \\
\hline \multirow[t]{3}{*}{$\begin{array}{l}\text { Mechanical } \\
\text { Integrity Testing } \\
\text { (ACZ/USDW } \\
\text { wells excluded) }\end{array}$} & $\begin{array}{l}\text { PNC and temperature } \\
\text { logging (frequency } \\
\text { shown for injection } \\
\text { wells) }\end{array}$ & $\begin{array}{l}\text { Once after well } \\
\text { completion }\end{array}$ & Annual & Annual & Annual & $\begin{array}{l}\text { Annual until } \\
\text { wells are } \\
\text { plugged }\end{array}$ \\
\hline & $\begin{array}{l}\text { Cement-evaluation and } \\
\text { casing inspection logs }\end{array}$ & $\begin{array}{l}\text { Once after well } \\
\text { completion }\end{array}$ & $\begin{array}{l}\text { During well } \\
\text { workovers }\end{array}$ & $\begin{array}{l}\text { During well } \\
\text { workovers }\end{array}$ & $\begin{array}{l}\text { During well } \\
\text { workovers }\end{array}$ & NA \\
\hline & $\begin{array}{l}\text { Annular pressure } \\
\text { monitoring }\end{array}$ & NA & Continuous & Continuous & Continuous & NA \\
\hline $\begin{array}{l}\text { Pressure Fall-Off } \\
\text { Testing }\end{array}$ & $\begin{array}{l}\text { Injection-well pressure } \\
\text { fall-off testing }\end{array}$ & NA & Every 5 yr & Every $5 \mathrm{yr}$ & Every 5 yr & NA \\
\hline \multirow[t]{2}{*}{$\begin{array}{l}\text { Groundwater } \\
\text { Quality } \\
\text { Monitoring }\end{array}$} & $\begin{array}{l}\text { Fluid sampling and } \\
\text { analysis in ACZ and } \\
\text { USDW monitoring wells }\end{array}$ & 3 events & Quarterly & $\begin{array}{l}\text { Semi- } \\
\text { Annual }\end{array}$ & Annual & Every 5 yr \\
\hline & $\begin{array}{l}\text { Electronic } \mathrm{P} / \mathrm{T} / \mathrm{SpC} \\
\text { probes installed in } \mathrm{ACZ} \\
\text { and USDW wells }\end{array}$ & $1 \mathrm{yr} \min$ & Continuous & Continuous & Continuous & Continuous \\
\hline \multirow{2}{*}{$\begin{array}{l}\text { Direct } \mathrm{CO}_{2} \\
\text { Plume and } \\
\text { Pressure-Front } \\
\text { Monitoring }\end{array}$} & $\begin{array}{l}\text { Fluid sample collection } \\
\text { and analysis in SLR } \\
\text { monitoring wells }\end{array}$ & 3 events & Quarterly & $\begin{array}{l}\text { Semi- } \\
\text { Annual }\end{array}$ & Annual & Every $5 \mathrm{yr}$ \\
\hline & $\begin{array}{l}\text { Electronic } \mathrm{P} / \mathrm{T} / \mathrm{SpC} \\
\text { probes installed in SLR } \\
\text { wells }\end{array}$ & $1 \mathrm{yr} \min$ & Continuous & Continuous & Continuous & Continuous \\
\hline \multirow{4}{*}{$\begin{array}{l}\text { Indirect } \mathrm{CO}_{2} \\
\text { Plume and } \\
\text { Pressure-Front } \\
\text { Monitoring }\end{array}$} & $\begin{array}{l}\text { Passive seismic } \\
\text { monitoring }\end{array}$ & $1 \mathrm{yr} \min$ & Continuous & Continuous & Continuous & Continuous \\
\hline & $\begin{array}{l}\text { Integrated deformation } \\
\text { monitoring }\end{array}$ & $1 \mathrm{yr} \min$ & Continuous & Continuous & Continuous & Continuous \\
\hline & Time-lapse gravity & 3 events & Annual & Annual & Annual & NA \\
\hline & $\begin{array}{l}\text { PNC logging of RAT } \\
\text { installations }\end{array}$ & 3 events & Quarterly & Quarterly & Annual & Annual \\
\hline
\end{tabular}

$\mathrm{ACZ}=$ above-confining-zone; $\mathrm{NA}=$ not applicable; $\mathrm{PNC}=$ pulsed-neutron capture; $\mathrm{P} / \mathrm{T} / \mathrm{Spc}=$ pressure, temperature, and specific conductance; RAT = reservoir access tube; SLR = single-level in-reservoir; USDW $=$ underground source of drinking water. 


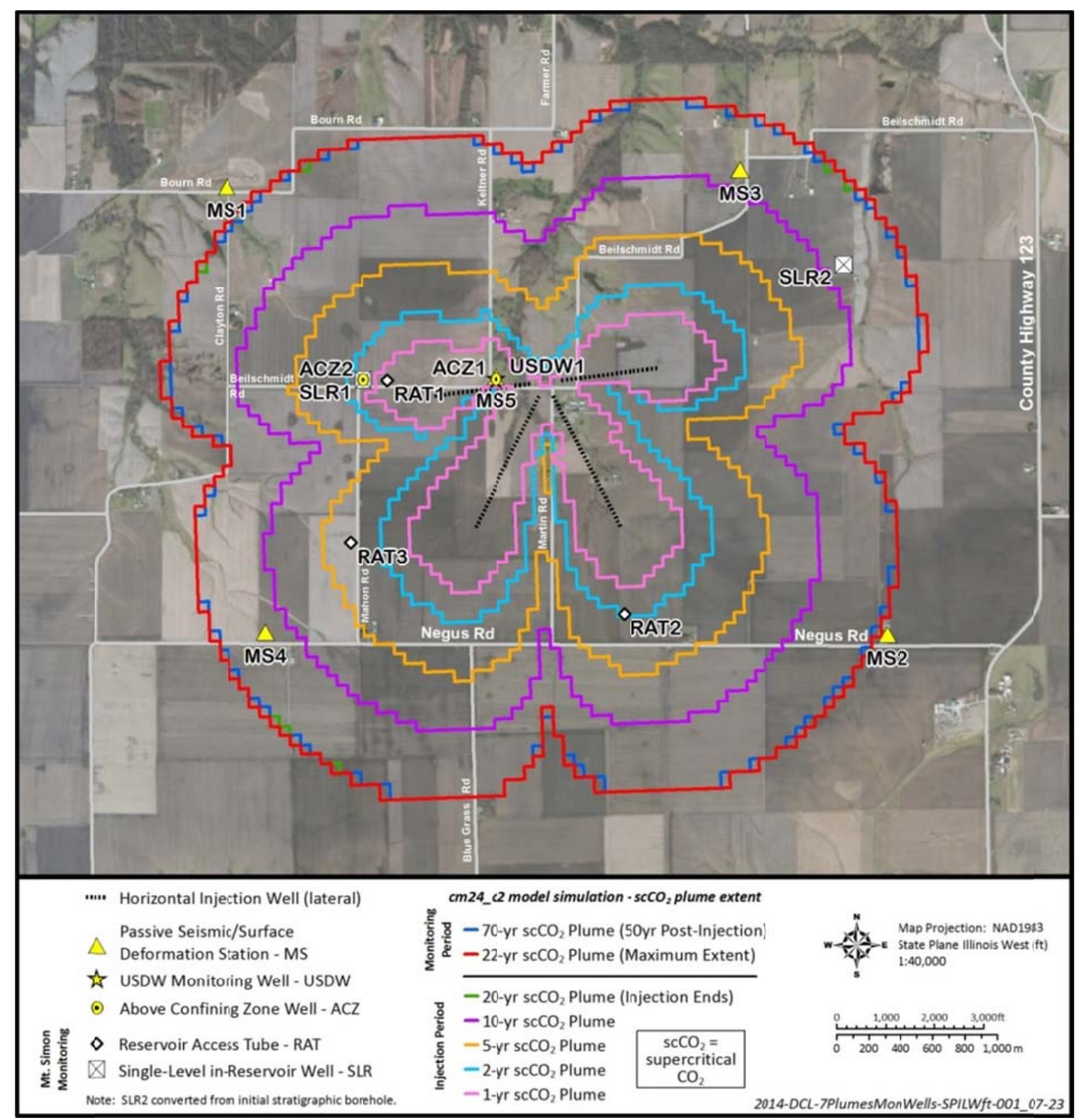

Figure 6. Monitoring network layout in relation to the proposed injection-well configuration design and resulting predictions of $\mathrm{scCO}_{2}$ plume extent. 


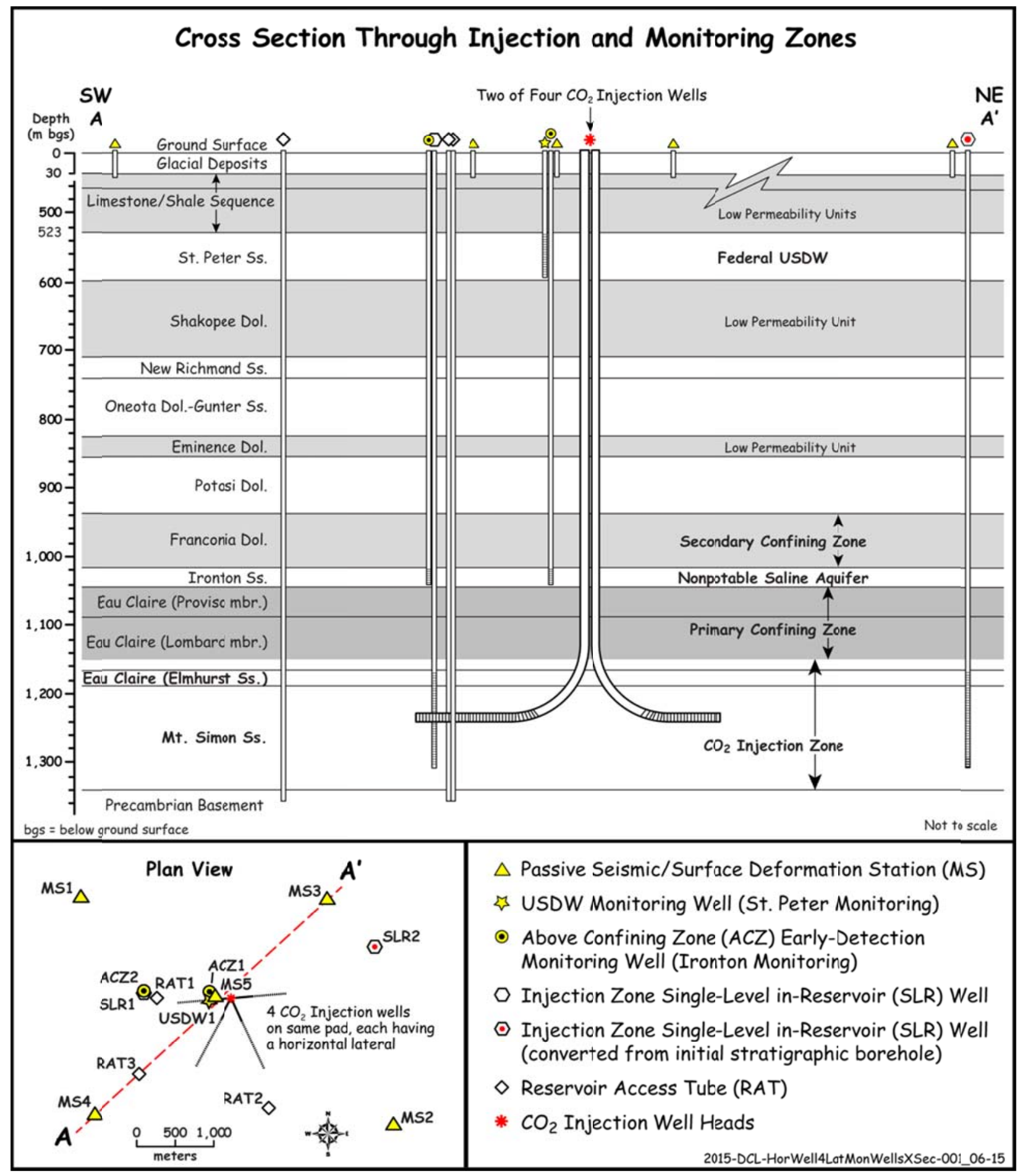

Figure 7. Cross-sectional view of the injection and monitoring well network design.

In addition to the five planned monitoring wells, the design incorporates three reservoir access tube (RAT) installations, which are used to monitor $\mathrm{CO}_{2}$ saturation across the injection zone and primary confining zone; measurements from the RAT installations would be used to track the evolution of the $\mathrm{CO}_{2}$ plume. The RATs are non-perforated, cemented casings used to monitor for $\mathrm{CO}_{2}$ arrival and quantify saturation levels via downhole PNC geophysical logging across the reservoir and confining zone. $\mathrm{PNC}$ logging is a proven method for quantifying $\mathrm{CO}_{2}$ saturation around a borehole. These three monitoring installations are located at increasing distances from the 
injection site to provide measures of $\mathrm{CO}_{2}$ saturation at the predicted 1-, 2-, and 3- to 4-year arrival times, respectively. The three RAT installations are also distributed across three different azimuthal directions, providing $\mathrm{CO}_{2}$ arrival information for three of the four predicted lobes of the $\mathrm{CO}_{2}$ plume. These near-field $\mathrm{CO}_{2}$ saturation measurements would allow for calibration of the numerical model early in the injection phase of the project and verify whether the $\mathrm{CO}_{2}$ plume was developing as predicted. The RAT installations would be monitored over the life of the project to assess the potential for vertical migration of $\mathrm{CO}_{2}$ into the confining zone material.

\subsection{Geophysical Monitoring Network Design}

Geophysical monitoring methods are sensitive to subsurface conditions that can change as a result of changes in fluid saturation or pressure associated with $\mathrm{CO}_{2}$ injection. Geophysical methods considered for the FutureGen 2.0 storage site included electrical resistivity tomography monitoring, passive seismic monitoring, integrated deformation monitoring, two-dimensional (2D) and three-dimensional (3D) reflection seismic surveys, vertical seismic profiling, cross-well seismic surveys, time-lapse gravity surveys, magnetotellurics and controlled source electromagnetic surveys, and PNC logging. This comprehensive suite of technologies was evaluated with respect to site-specific conditions and subjected to a screening process; based on this evaluation, suitable methodologies were selected for inclusion in the monitoring program design. This selection process considered the level of sensitivity, spatial resolution, costs to install and operate, potential interference with other monitoring activities, and site access and landowner acceptance limitations. Geophysical methods that were selected for inclusion in the monitoring program design include passive seismic monitoring, integrated deformation monitoring, time-lapse gravity, and PNC logging. A detailed discussion of this design evaluation and screening process is presented by Strickland et al. (2014) and Vermeul et al. (2014a). A brief discussion of passive seismic and integrated deformation monitoring is provided below. Time-lapse gravity was included in the monitoring program design as a supplemental and opportunistic measurement that can easily be collected along with periodic deformation measurements. PNC logging was included because it is an industry standard methodology for measuring $\mathrm{CO}_{2}$ saturation.

Passive seismic monitoring can be used to both identify the occurrence of, and determine the location of, injection-related seismic events that may occur. Due to the potential for significant induced seismicity (Zoback and Gorelick, 2012) at commercial-scale CCS sites, a passive seismic monitoring network is an important component of the monitoring program. Various passive seismic monitoring network configurations were investigated to assess their performance under site-specific conditions. Several key factors that affect the performance of a seismic sensor network were evaluated, including sensor characteristics (e.g., sensitivity, noise floor, and bandwidth), network geometry, installation design, and site properties. Two general station types were considered in the design: nearsurface stations and deep borehole arrays. A network of five surface stations was designed with a broadband seismometer and geophone emplaced within a shallow borehole (approximately $100 \mathrm{~m}$ deep), along with a strongmotion accelerometer installed within a vault at the surface. Two deep borehole arrays were designed with a string of robust three-component sensors cemented on the outside of well casing, extending from just above the primary confining zone to approximately $300 \mathrm{~m}$ below ground surface. The locations of the seismic monitoring stations are shown in Figure 6 and Figure 7. A modeling assessment was conducted to examine the performance of a number of possible network configurations (Vermeul et al., 2014a). For each case, 2D horizontal and vertical location error maps were generated along transects at various depths. These estimates of seismic event location uncertainty were used to evaluate various network configurations and to select the design for inclusion in the overall monitoring program design.

A modeling analysis was also performed to predict injection-related surface deformation under FutureGen 2.0 storage site conditions. A 3D geomechanical model was used to calculate the expected deformation due to the simulated pressure field produced by the $\mathrm{CO}_{2}$ injection; an analytical model was also applied and provided similar results (Vermeul et al., 2014a). The 3D geomechanical modeling analysis was conducted using the STOMPCO2/ABAQUS ${ }^{\circledR}$ sequentially coupled simulator (Murray et al., 2014). Material properties for the analyses were derived for the 30-layer model from geophysical well logs generated during drilling of the initial stratigraphic borehole and from supplemental data available in the literature. The median values of Young's modulus and the Poisson ratio were taken directly from the geophysical logs. STOMP-CO2 was used to model the flow and transport of $\mathrm{CO}_{2}$ for a 20 -year injection period at an injection rate of $1.1 \mathrm{MMT}^{-} \mathrm{CO}_{2}$ per year. The information from STOMP-CO2 was then passed to a 3D finite element model (3DS, ABAQUS ${ }^{\mathbb{B}}$ ) at selected time steps, which calculated the 3D strains (including deformation at the surface), stresses, and fluid pressure. The maximum 
predicted deformation of $20 \mathrm{~mm}$ would occur close to the injection well within the region of maximum pressure increase and deformations of between 8 and $12 \mathrm{~mm}$ were predicted at the $\mathrm{CO}_{2}$ plume extent.

An integrated approach was proposed for monitoring surface deformation at the FutureGen 2.0 storage site that included both orbital InSAR and ground measurements (i.e., global positioning system [GPS] stations with tiltmeters and differential GPS [DGPS] surveys). These surface deformation monitoring stations were planned to be collocated with the five surface-based seismic monitoring stations. Sub-centimeter accuracies are typical for both InSAR and precision differential GPSs, and thus it is expected that deformation would be detectable using these approaches. The authors recognize that agricultural practices in the area would likely result in temporal changes in surface elevation not associated with $\mathrm{CO}_{2}$ injection. To address this potential source of interference, the design includes permanent GPS stations, InSAR artificial reflectors, and tiltmeters, along with annual DGPS surveys performed across a network of 81 permanent stations located along roadways that would be minimally affected by agricultural practices.

\subsection{Near-Surface Environmental Monitoring Network Design}

At the direction of the UIC Program Director, no surface or near-surface monitoring methodologies were included as a requirement of the UIC permit. Even though near-surface monitoring was not a permit requirement at the proposed FutureGen 2.0 storage site, the Alliance initiated several approaches, including surficial groundwater monitoring, surface-water monitoring, soil-gas monitoring, atmospheric monitoring, and an evaluation of spatiotemporal mapping of vegetation and surface conditions through remote sensing. Initially, only the collection of baseline data sets was included in the monitoring program design. The need for additional near-surface monitoring approaches would be periodically evaluated throughout the life of the project, and selected monitoring technologies would be reinstituted if conditions warranted. Given our current conceptual understanding of the subsurface environment at the proposed FutureGen 2.0 storage site, early and appreciable impacts on near-surface environments would not be expected, so extensive networks of surficial aquifer, surface-water, soil-gas, and atmospheric monitoring stations were not included in the monitoring program design.

\section{Summary}

The FutureGen 2.0 Project developed an initial subsurface design for a geologic storage site capable of receiving up to $22 \mathrm{MMT}$ of $\mathrm{CO}_{2}$ at a rate of $1.1 \mathrm{MMT} / \mathrm{yr}$ (i.e., a 20 -year injection period, which would be followed by a 50year-long post-injection monitoring period). Integral to this subsurface design is a testing and monitoring program design that would be used to track and account for the mass of $\mathrm{CO}_{2}$ injected and protect USDWs from storagerelated impacts. The FutureGen 2.0 Project selected a suite of monitoring technologies with the objective of addressing identified sources of project risk and meeting all requirements of a Class VI permitting process. The most significant project risk was expected to be associated with the potential for injection-related induced seismicity. Other identified sources of moderate project risk included asymmetric, heterogeneous development of the $\mathrm{CO}_{2}$ plume and leakage associated with project-installed wells. Based on regional and site-specific geologic information, the risk associated with other possible sources of confining zone leakage was considered to be low. The monitoring program design comprises both direct and indirect monitoring methodologies, including 1) direct monitoring of the injection stream, reservoir, ACZ, and USDW monitoring zones, and 2) indirect geophysical monitoring to provide a measure of $\mathrm{CO}_{2}$ plume evolution/symmetry and to support assessment of the potential for injection-related induced seismicity.

\section{Acknowledgements}

The FutureGen 2.0 project was supported by U.S. federal funding from the American Recovery and Reinvestment Act. The program was implemented under Cooperative Agreement DE-FE0001882 between the U.S. Department of Energy and the FutureGen Industrial Alliance, Inc., a non-profit membership organization created to benefit the public interest and the interests of science through research, development, and demonstration of near-zero emissions coal technology. Members of the Alliance include some of the largest coal producers, coal users, and coal equipment suppliers in the world. For more information about FutureGen 2.0, please visit www.futuregenalliance.org. 


\section{References}

Alliance (FutureGen Industrial Alliance, Inc.), 2012 Borehole Completion and Characterization Summary Report for the Stratigraphic Well, Morgan County, Illinois FG-RPT-015 Rev 1, Washington, D.C.

Alliance (FutureGen Industrial Alliance, Inc.), 2013 Underground Injection Control Permit Applications for FutureGen 2.0 Morgan County Class VI UIC Wells 1, 2, 3, and 4 - SUPPORTING DOCUMENTATION FG-RPT-017-Revision 1, Jacksonville, Illinois.

Alliance (FutureGen Industrial Alliance, Inc.), 2015 Pipeline and Regional Carbon Capture Storage Project Final Scientific and Technical Report prepared for the U.S. Department of Energy, Washington, D.C.

Amonette et al., 2014 J.E. Amonette, T.A. Johnson, C.F. Spencer, L. Zhong, J.E. Szecsody, V.R. Vermeul. Geochemical Monitoring Considerations for the FutureGen 2.0 Project GHGT-12, Energy Procedia 63 (2014) pp. 4095-4111

Arts et al., 2008 R. Arts, A. Chadwick, O. Eiken, S. Thibeau, S. Nooner. Ten years' experience of monitoring $\mathbf{C O}_{2}$ injection in the Utsira sand at Sleipner (offshore Norway) First Break 26 (2008) pp. 65-72

Bachu, $2008 \mathrm{~S}$. Bachu $\mathbf{C O}_{2}$ storage in geological media: Role, means, status and barriers to deployment Prog. Energ. Combust. 34 (2008), pp. 254-273.

Beuabien et al., 2013 S.E. Beaubien, D.G. Jones, F. Gal, A.K.A.P. Barkwith, G. Braibant, J.-C. Baubron, G. Ciotoli, S. Graziani, T.R. Lister, S. Lombardi, K. Michel, F. Quattrocchi, M.H. Strutt Monitoring of near-surface gas geochemistry at the Weyburn, Canada, $\mathrm{CO}_{2}$-EOR site, 2001-2011 Int. J. Greenh. Gas Control 16 (2013) (S1), pp. S236-S262.

Belcher and Sichelstiel, 1995 D.M. Belcher, K.D. Sichelstiel Case Study: the observational approach and fasttrack remediation of NSB kings bay Fed. Facil. Environ. J. 6 (2) (1995), pp. 77-90.

Birkholzer et al., 2011 J.T. Birkholzer, J.P. Nicot, C.M. Oldenburg, Q. Zhou, S. Kraemer, K. Bandilla Brine flow up a well caused by pressure perturbation from geologic carbon sequestration: Static and dynamic evaluations Int. J. Greenh. Gas Control 5 (4) (2011), pp. 850-861.

Birkholzer and Zhou, 2009 J.T. Birkholzer, Q. Zhou Basin-scale hydrogeologic impacts of CO $\mathbf{C O}_{2}$ storage: Capacity and regulatory implications Int. J. Greenh. Gas Control 3 (6), 745-756.

Birkholzer et al. 2009 J.T. Birkholzer, Q. Zhou, C-F Tsang Large-scale impact of $\mathbf{C O}_{2}$ storage in deep saline aquifers: A sensitivity study on pressure response in stratified systems. Int. J. Greenh. Gas Control 3 (2) (2009), pp. 181-194.

Bonneville et al., 2013 A. Bonneville, T.J. Gilmore, E.C. Sullivan, V.R. Vermeul, M.E. Kelley, S.K. White, D. Appriou, B.N. Bjornstad, J.L. Gerst, N. Gupta, J.A. Horner, C. McNeil, M.A. Moody, W.M. Rike, F.A. Spane, P.D. Thorne, E.R. Zeller, Z.F. Zhang, J. Hoffman, K.K. Humphreys Evaluating the Suitability for CO $\mathbf{C O}_{2}$ Storage at the FutureGen 2.0 Site, Morgan County, Illinois, USA. Energy Procedia 37 (2013), pp. 6125-6132.

Butsch et al., 2013 R. Butsch, A.L. Brown, B. Bryans, C. Kolb, S. Horvorka Integration of well-based monitoring technologies: Lessons learned at SECARB study, Cranfield, MS Int. J. Greenh. Gas Control 18 (2013) pp. 409-420.

Carman et al., 2014 C.H. Carman, R.A. Locke II, and C.S. Blakley Update on Soil CO Flux Monitoring at the Illinois Basin - Decatur Project, USA GHGT-12, Energy Procedia 63 (2014), pp. 3869-3880.

Chadwick et al., 2008 A. Chadwick, R. Arts, C. Bernstone, F. May, S. Thibeau, P. Zweigel Best Practice for the Storage of $\mathrm{CO}_{2}$ in Saline Aquifers British Geological Survey ISBN: 978-0-85272-610-5. 
Couëslan et al., 2013 M.L. Couëslan, R. Butsch, R. Will, R.A. Locke II Integrated reservoir monitoring at the Illinois Basin - Decatur Project GHGT-12, Energy Procedia 63 (2013), pp. 2836-2847.

EPA (U.S. Environmental Protection Agency), 2013 Geologic Sequestration of Carbon Dioxide, Underground Injection Control (UIC) Program Class VI Well Testing and Monitoring Guidance EPA 816-R-13-001, Office of Water (4606M), Washington, D.C.

Fahrner et al., 2012 S. Fahrner, D. Schafer, A. Dahmke A monitoring strategy to detect $\mathrm{CO}_{2}$ intrusion in deeper freshwater aquifers Int. J. Greenh. Gas Control 9 (2012) pp. 262-271.

Finley, 2014 R.J. Finley An overview of the Illinois Basin - Decatur Project Greenh. Gas Sci. Technol. 4 (2014), pp. 571-579 doi: 10.1002/ghg.1433.

Flury and Wai, 2003, M. Flury, N.N. Wai Dyes as tracers for vadose zone hydrology Rev. Geophys. 41 (2003), p. 1002 .

Gal et al., 2014 F. Gal, J. Lions, Z. Pokryszka, P. Gombert, S. Grellier, F. Prevot, Y. Darmoul, P. Squarcioni $\mathbf{C O}_{2}$ leakage in a shallow aquifer - Observed changes in case of small release GHGT-12, Energy Procedia 63 (2014), pp. 4112-4122.

Gale, 2004 J. Gale Geological storage of $\mathrm{CO}_{2}$ : What do we know, where are the gaps and what more needs to be done? Energy 29 (2004), pp. 1329-1338.

Gilliland et al., 2013 E.S. Gilliland, N. Ripepi, M. Conrad, M.J. Miller, M. Karmis Selection of monitoring techniques for a carbon storage and enhanced coalbed methane recovery pilot test in the Central Appalachian Basin Int. J. of Coal Geol. 118 (2013), pp. 105-112.

Gollakota and McDonald, $2012 \mathrm{~S}$. Gollakota, S. McDonald $\mathbf{C O}_{2}$ capture from ethanol production and storage into the Mt Simon Sandstone. Greenh. Gas Sci. Tech. 2 (2012), pp. 346-351 doi: 10.1002/ghg.

Hannis, S 2010 Monitoring technologies used at some geologic $\mathbf{C O}_{2}$ storage sites Innovation for Sustainable Production (i-SUP) conference proceedings, Bruges, April 18-21, 2010, pp. 1-5.

Hepple and Benson, 2005 R.P. Hepple, S.M. Benson Geologic storage of carbon dioxide as a climate change mitigation strategy: performance requirements and the implications of surface seepage Environ. Geol. 47 (2005), pp. 576-585 doi: 10.1007/s00254-004-1181-2.

Hovorka et al., 2011 S.D. Hovorka, T.A. Meckel, R.H. Trevino, J. Lu, J-P. Nicot, J-W. Choi, D. Freeman, P. Cook, T.M. Daley, J.B. Ajo-Franklin, B.M. Freifeild, C. Doughty, C.R.Carrigan, D. La Brecque, Y.K. Kharaka, J.J. Thordsen, T.J. Phelps, C. Yang, K.D. Romanak, T. Zhang, R.M. Holt, J.S. Lindler, and R.J. Butsch Monitoring a large volume $\mathrm{CO}_{2}$ injection: Year two results from SECARB project at Denbury's Cranfield, Mississippi, USA GHGT-10, Energy Procedia 4 (2011), pp. 3478-3485.

Hudak and Loaiciga, 1992 P.F. Hudak, H.A. Loaiciga A location Modeling Approach for Groundwater Monitoring Network Augmentation Water Resour. Res. 28(3) (1992) pp. 643-649.

Ivanova et al., 2012 A. Ivanova, A. Kashubin, N. Juhojuntti, J. Kummerow, J. Henninges, C. Juhlin, S. Luth, M. Ivandic Monitoring and volumetric estimation of injected $\mathrm{CO}_{2}$ using $4 \mathrm{D}$ seismic, petrophysical data, core measurements and well logging: a case study at Ketzin, Germany Geophys. Prospect. 60 (2012), pp. 957-973.

Johnson et al., 2011a G. Johnson, B. Mayer, M. Shevalier, M. Nightingale, I. Hutcheon Tracing the movement of $\mathrm{CO}_{2}$ injected into a mature oilfield using carbon isotope abundance ratios: The example of the Pembina Cardium $\mathrm{CO}_{2}$ Monitoring project Int. J. Greenh. Gas Control 5 (2011a), pp. 933-941.

Johnson et al., 2011b G. Johnson, B. Mayer, M. Nightingale, M. Shevalier, I. Hutcheon Using oxygen isotope ratios to quantitatively assess trapping mechanisms during $\mathrm{CO}_{2}$ injection into geological reservoirs: The Pembina case study Chem. Geol. 283 (2011b), pp. 185-193 
Johnson et al., 2009 G. Johnson, M. Raistrick, B. Mayer, M. Shevalier, S. Taylor, M. Nightingale, I. Hutcheon The use of stable isotope measurements for monitoring and verification of $\mathrm{CO}_{2}$ storage GHGT-9. Energy Procedia 1 (2009), pp. 2315-2322

Jung et al., 2013 Y. Jung, Q. Zhou, J.T. Birkholzer Early detection of brine and $\mathrm{CO}_{2}$ leakage through abandoned wells using pressure and surface-deformation monitoring data: Concept and demonstration Adv. in Water Resour. 62 (2013), pp. 555-569

Keating et al., 2013 E.H. Keating, J.A. Hakala, H. Viswanathan, J.W. Carey, R. Pawar, G.D. Guthrie, J. FessendenRahn $\mathrm{CO}_{2}$ leakage impacts on shallow groundwater: Field-scale reactive-transport simulations informed by observations at a natural analog site Appl. Geochem. 30 (2013), pp. 136-147

Kharaka et al., 2006 Y.K. Kharaka, D.R. Cole, S.D. Hovorka, W.D. Gunter, K.G. Knauss, B.M. Freifeld Gas-waterrock interactions in Frio Formation following $\mathrm{CO}_{2}$ injection: Implications for the storage of greenhouse gases in sedimentary basins Geology 34(7) (2006), pp. 577-580 doi: 10.1130/G22357.1

Kharaka et al., 2010 Y.K. Kharaka, J.J. Thordsen, E. Kakouros, G. Ambats, W.N. Herkelrath, S.R. Beers, J.T. Birkholzer, J.A. Apps, N.F. Spycher, L. Zheng, R.C. Trautz, H.W. Rauch, K.S. Gullickson Changes in the chemistry of shallow groundwater related to the 2008 injection of $\mathrm{CO}_{2}$ at the ZERT field site, Bozeman, Montana Environ. Earth Sci. 60 (2010) pp. 273-284 doi: 10.1007/s12665-009-0401-1

Kolata and Nelson, 1991 D.R. Kolata, J. Nelson "Tectonic History of the Illinois Basin.” In Interior Cratonic Basins, M.W. Leighton, D.R. Kolata, D.F Oltz, J.J. Eidel (eds.), pp. 263-285, Memoir 51, American Association of Petroleum Geologists. Tulsa, Oklahoma

Korose et al., 2013 C.P. Korose, R.A. Locke II, C.S. Blakley, C.H. Carman Integration of near-surface monitoring information using ArcGIS at the Illinois Basin - Decatur Project, USA GHGT-12, Energy Procedia 63 (2013), pp. 3945-3955

Litynski et al., 2013 J. Litynski, D. Vikara, M. Webster, R. Srivastava U.S. Department of Energy Efforts to Advance Remote Sensing Technologies for Monitoring Geologic Storage Operations. GHGT-11, Energy Procedia 37 (2013), 4114-4127

Locke et al., 2011 R.A. Locke II, I.G. Krapac, J.L. Lewicki, E. Curtis-Robinson Characterizing near-surface $\mathbf{C O}_{2}$ conditions before injection - Perspectives from a CCS project in the Illinois Basin, USA GHGT-10, Energy Procedia 4 (2011), 3306-3313

Madsen et al., 2009 R. Madsen, L. Xu, B. Claassen, D. McDermitt Surface Monitoring Method for Carbon Capture and Storage Projects GHGT-9, Energy Procedia 1 (2009), pp. 2161-2168

Marino et al., 2011 B.D.V. Marino, M. Bright, G. Gronniger Design and package of a ${ }^{14} \mathbf{C O}_{2}$ field analyzer: The Global Monitor Platform SPIE 8156 (2011) 81560E-1-81560E-15

Mathieson et al., 2011 A. Mathieson, J. Midgely, I. Wright, N. Saoula, P. Ringrose In Salah $\mathbf{C O}_{2}$ Storage JIP: $\mathbf{C O}_{2}$ sequestration monitoring and verification technologies applied at Krechba, Algeria Energy Procedia 4 (2011), pp. 3596-3603 doi:10.1016/j.egypro.2011.02.289

Matter et al., 2011 J.M. Matter, W.S. Broecker, S.R. Gislason, E. Gunnlaugsson, E.H. Oelkers, M. Stute, H. Sigurdardottir, A. Stefansson, H.A. Alfredsson, E.S. Aradottir, G. Axelsson, B. Sigfusson, D. Wolff-Boenisch The CarbFix pilot project—storing carbon dioxide in basalt Energy Procedia 4 (2011), pp. 5579-5585

McAlexander et al., 2011 I. McAlexander, G.H. Rau, J. Liem, T. Owano, R. Fellers, D. Baer, M. Gupta Deployment of a carbon isotope ratiometer for the monitoring of $\mathrm{CO}_{2}$ sequestration leakage Anal. Chem. 83 (2011), pp. 6223-6229

McGarr, A 2014 Maximum magnitude earthquakes induced by fluid injection J. Geophys. Res. Solid Earth 119 (2014), pp. 1008-1019 doi:10.1002/2013JB010597 
Moni and Rasse, 2014 C. Moni, D.P. Rasse Detection of simulated leaks from geologically stored $\mathbf{C O}_{2}$ with ${ }^{13} \mathbf{C}$ monitoring Int. J. Greenh. Gas Control 26 (2014), pp. 61-68

Mortazavi et al., 2013 B. Mortazavi, B.J. Wilson, F. Dong, M. Gupta, D. Baer Validation and application of cavity-enhanced, near-infrared tunable diode laser absorption spectrometry for measurements of methane carbon isotopes at ambient concentrations Environ. Sci. Tech. 47 (2013), pp. 11676-11684

Murray et al., 2014 C.J. Murray, B.N. Nguyen, Z. Hou, Z.F. Zhang, S.K. White Mechanical Evaluation of the Thermal Impact of $\mathrm{CO}_{2}$ Injection for a Range of Potential Injection Temperatures FG-02-RPT-0008, prepared for the FutureGen 2.0 Project, by Battelle-Pacific Northwest Division, Richland, Washington

Myers et al., 2013 M. Myers, L. Stalker, Bb Pejcic, A. Ross Tracers - Past, present and future applications in $\mathrm{CO}_{2}$ geosequestration Appl. Geochem. 30 (2013), pp. 125-135.

National Research Council, 2012 Induced Seismicity Potential in Energy Technologies National Academy of Sciences, Washington, D.C.

NETL (National Energy Technology Laboratory), 2009 Best Practices for: Monitoring, Verification and Accounting of $\mathrm{CO}_{2}$ Stored in Deep Geologic Formations DOE/NETL-311/081508 (www.netl.doe.gov),

NETL (National Energy Technology Laboratory), 2012 Best Practices for: Monitoring, Verification and Accounting of $\mathrm{CO}_{2}$ Stored in Deep Geologic Formations - 2012 Update DOE/NETL-2012/1568 (www.netl.doe.gov)

Person et al., 2010 M. Person, A. Banerjee, J. Rupp, C. Medina, P. Lichtner, C. Gable, R. Pawar, M. Celia, J. McIntosh, V. Bense Assessment of basin-scale hydrologic impacts of $\mathrm{CO}_{2}$ sequestration, Illinois basin Int. J. Greenh. Gas Control 4 (2010), pp. 840-854

Ringrose et al., 2009 P. Ringrose, M. Atbi, D. Mason, M. Espinassous, Ø. Myhrer, M. Iding, A. Mathieson, I. Wright Plume development around well KB-502 at the In Salah $\mathbf{C O}_{2}$ storage site First Break 27 (2009), pp. $85-89$

Romanak et al., 2012 K.D. Romanak, P.C. Bennett, C. Yang, S.D. Hovorka Process-based approach to $\mathbf{C O}_{2}$ leakage detection by vadose zone gas monitoring at geologic $\mathrm{CO}_{2}$ storage sites Geophys. Res. Lett. 39 (2012), L15405 doi: 10.1029/2012GL052426

Rose et al., 2001 P.E. Rose, W.R. Benoit, P.M. Kilbourn The application of the polyaromatic sulfonates as tracers in geothermal reservoirs Geothermics 30 (2001), pp. 617-640

Sakurai et al., 2005 S. Sakurai, T.S. Ramakrishnan, A. Boyd, N. Mueller, S. Hovorka Monitoring saturation changes for $\mathrm{CO}_{2}$ sequestration: petrophysical support of the Frio brine pilot experiment 46th Annual Logging Symposium Transactions, Society of Petrophysicists and Well Log Analysts, New Orleans, Louisiana

Senum et al., 1997 G.I. Senum, T.W. D’Ottavio, W.M. Loss, R.W. Goodrich, D.J. Spandau, R.N. Dietz HPFF Cable Leak Location Using Perfluorocarbon Tracers TR-109086, 7905-01, Electric Power Research Institute, Palo Alto, California

Schloemer et al., 2013 S. Schloemer, M. Furche, I. Dumke, J. Poggenburg, A. Bahr, C. Seeger, A. Vidal, E. Faber A review of continuous soil gas monitoring related to CCS - Technical advances and lessons learned Appl. Geochem. 30 (2013), pp. 148-160

Seto and McRae, 2011 C.J. Seto, G.J. McRae Reducing Risk in Basin Scale $\mathbf{C O}_{2}$ Sequestration: A Framework for Integrated Monitoring Design Environ. Sci. Tech. 45 (2011), pp. 845-859 10.1021/es102240w

Siegrist et al., 2011 R.L. Siegrist, M. Crimi, T.J. Simpkin In Situ Chemical Oxidation for Groundwater Remediation, Vol. 3, of SERDP ESTCP Environmental Remediation Technology, Springer, New York 
Stetzenbach et al., 1982 K.J. Stetzenbach, S.L. Jensen, G.M. Thompson Trace enrichment of fluorinated organic acids used as groundwater tracers by liquid chromatography Environmental Science and Technology 16 (1982), pp. $250-254$

Strickland et al., 2014 C.E. Strickland, V.R. Vermeul, A. Bonneville, E.C. Sullivan, T.C. Johnson, F.A. Spane, T.J. Gilmore Geophysical Monitoring Methods Evaluation for the FutureGen 2.0 Project GHGT-12, Energy Procedia 63 (2014), pp. 4394-4403

Sun and Nicot, 2012 A.Y. Sun, J-P. Nicot Inversion of pressure anomaly data for detecting leakage at geologic carbon sequestration sites Adv. in Water Resour. 44 (2012), pp. 20-29

Sun et al., 2013 A.Y. Sun, J-P. Nicot, X. Zhang Optimal design of pressure-based, leakage detection monitoring networks for geologic carbon sequestration repositories Int. J. Greenh. Gas Control 19 (2013), pp. 251-261

Vasco et al., 2010 D.W. Vasco, A. Rucci, A. Ferretti, F. Novali, R.C. Bissell, P.S. Ringrose, A.S. Mathieson, I.W. Wright Satellite-based measurements of surface deformation reveal fluid flow associated with the geological storage of carbon dioxide Geophys. Res. Lett. 37 (2010), L03303 doi: 10.1029/2009GL041544, 2010

Verdon et al., 2013 J.P. Verdon, J-M. Kendall, A.L. Stork, R.A. Chadwick, D.J. White, R.C. Bissell Comparison of geomechanical deformation induced by meagatonne-scale $\mathrm{CO}_{2}$ storage at Sleipner, Weyburn and In Salah In PNAS 110 (30) (2013), pp. E2762-E2771

Vermeul et al., 2014a V.R. Vermeul, V.R., J.E. Amonette, C.E. Strickland, J.E. Szecsody, M.D. Williams, A. Bonneville, T.A. Johnson, T.C. Johnson, M. Oostrom, S.L. Porse, F.A. Spane, C.F. Spencer, J.N. Thomle

FutureGen 2.0 Monitoring Systems Design Basis and Technology Selection: Geohydrologic, Geochemical, and Geophysical Considerations PNWD-4435, Pacific Northwest National Laboratory, Richland, Washington

Vermeul et al., 2014b V.R. Vermeul, A. Bonneville, M.E. Kelley, R.D. Mackley, C.E. Strickland, J.E. Szecsody, P.D. Thorne, M.D. Williams FutureGen 2.0 - CO2 Pipeline and Storage Project Testing and Monitoring Plan FG-02-PLN-TAMP, PNWD-4428, Pacific Northwest National Laboratory, Richland, Washington

Wells et al., 2007 A.W. Wells, J.R. Diehl, G. Bromhal, B.R. Strazisar, T.H. Wilson, and C.M. White The use of tracers to assess leakage from the sequestration of $\mathrm{CO}_{2}$ in a depleted oil reservoir, New Mexico, USA Appl. Geochem. 22 (2007), pp. 996-1016

Wells et al., 2013 A.W. Wells, J.R. Diehl, B.R. Strazisar, T.H. Wilson, D.C. Stanko Atmospheric and soil-gas monitoring for surface leakage at the San Juan Basin $\mathrm{CO}_{2}$ pilot test site at Pump Canyon New Mexico, using perfluorocarbon tracers, $\mathbf{C O}_{2}$ soil-gas flux and soil-gas hydrocarbons Int. J. Greenh. Gas Control 14 (2013), pp. $227-238$

Wells et al., 2010 A. Wells, B. Strazisar, J.R. Diehl, G. Veloski Atmospheric tracer monitoring and surface plume development at the ZERT pilot test in Bozeman, Montana, USA Environ. Earth Sci. 60 (2010), pp. 299-305

White et al., 2003 C.M. White, B.R. Strazisar, E.J. Granite, J.S. Hoffman, H.W. Pennline Separation and Capture of $\mathrm{CO}_{2}$ from Large Stationary Sources and Sequestration in Geological Formations - Coalbeds and Deep Saline Aquifers J. Air \& Waste Mgt. Assoc. 53 (6) (2003), pp. 645-715 doi: 10.1080/10473289.2003.10466206

White et al., 2012 M.D. White, D.H. Bacon, B.P. McGrail, D.J. Watson, S.K. White, Z.F. Zhang STOMP Subsurface Transport Over Multiple Phases: STOMP-CO2 and STOMP-CO2e Guide, Version 1.0 PNNL21268, Pacific Northwest National Laboratory, Richland, Washington

White et al., 2005 S.P. White, R.G. Allis, J. Moore, T. Chidsey, C. Morgan, W. Gwynn, M. Adams 2005 Simulation of reactive transport of injected $\mathrm{CO}_{2}$ on the Colorado Plateau, Utah, USA Chem. Geol. 217 (2005), pp. 387-405 
Whiting and Stevenson, 1965 L.L. Whiting, D.L. Stevenson The Sangamon Arch Circular 383, Illinois State Geological Survey, Urbana, Illinois

Will, 2012 B. Will Micoseismic Monitoring at IBDP: Systems Review and Current Status. Midwest Geological Sequestration Consortium, Champaign, Illinois

Williams et al., 2014 M.D. Williams, V.R. Vermeul, M. Oostrom, S.L. Porse, P.D. Thorne, J.E. Szecsody, J.A. Horner, .T.J. Gilmore Design Support of an Above Cap-rock Early Detection Monitoring System using Simulated Leakage Scenarios at the FutureGen 2.0 Site GHGT-12, Energy Procedia 63 (2014), pp. 4071-4082

Wolaver et al., 2013 B.D. Wolaver, S.D. Hovorka, R.C. Smyth Greensites and brownsites: Implications for $\mathbf{C O}_{2}$ sequestration characterization, risk assessment, and monitoring Int. J. Greenh. Gas Control 19 (2013), pp. 4962

Zhong et al., 2014 L. Zhong, J.E. Amonette, A.V. Mitroshkov, K.B. Olsen Transport of perfluorocarbon tracers and carbon dioxide in sediment columns - Evaluating the application of PFC tracers for $\mathbf{C O}_{2}$ leakage detection Appl. Geochem. 45 (2014), pp. 25-32.

Zobak and Gorelick, 2012 M.D. Zoback, S.M. Gorelick Earthquake triggering and large-scale geologic storage of carbon dioxide PNAS 109 (2012), pp. 10164-10168 